\title{
Patterns in macrozoobenthic assemblages indicate the state of the environment: insights from the Rhine-Meuse estuary
}

\author{
Sander Wijnhoven*, Herman Hummel
}

Monitor Taskforce, Netherlands Institute of Ecology, Centre for Estuarine and Marine Ecology (NIOO-CEME), Korringaweg 7, PO Box 140, NL-4401 NT, Yerseke, The Netherlands

\begin{abstract}
During the 1960s and early 1970s, the open system of the Rhine-Meuse estuary with a continuous salinity gradient was converted into a series of stagnant fresh water lakes separated by sluices from the North Sea coastal region 'Voordelta'. For the last $50 \mathrm{yr}$, the macrozoobenthic communities have been monitored intensively, and a large dataset is available on the responses of macrozoobenthic communities to strong disturbances (e.g. transitions in salinity, currents and dynamics) and gradual changes (e.g. changes in pollution and nutrient levels). The current study analyzes patterns and developments in macrozoobenthic compositions in terms of community descriptors (e.g. density, richness, evenness and diversity) and proportional distributions over feeding guilds (suspension feeders, deposit feeders, surface deposit feeders, herbivores, omnivores and predators). We compare historic and present situations and show that communities respond in similar ways (viz. peaking densities co-occurring with decreasing richness and diversity) to large disturbances and that the distribution over the feeding guilds indicates the state of the environment. Although the historic communities showed signs of system deterioration (mainly due to pollutants and nutrients), and at present, exotic species are abundant in the region, historic data were found to be valuable as a reference for what can be expected on the macrozoobenthic level following estuary restoration. This study showed the value of an undisturbed estuary in terms of total macrozoobenthic diversity compared to the series of fresh water lakes now separated from the Voordelta system and raises questions about future plans for a regulated salt water inlet that will be restricted to only $11.5 \mathrm{~km}$ inland.
\end{abstract}

KEY WORDS: Benthic communities - Species diversity - Feeding guilds - Quality indicators · Reference state $\cdot$ Salinity gradient $\cdot$ Multi-dimensional scaling Resale or republication not permitted without written consent of the publisher

\section{INTRODUCTION}

There has been a lot of debate as to whether open estuaries are more ecologically valuable than enclosed systems, especially for macrobenthic fauna (e.g. Nienhuis \& Huis in't Veld 1984, Nienhuis \& Smaal 1994, Bate et al. 2002, Hastie \& Smith 2006, Wolanski et al. 2006). Such enclosed systems are, for instance, estuaries turned into lakes, which can have a variety of salinities. In this debate the answer will largely depend on the targets and indicators, e.g. macrobenthic indica- tors, with which the nature value is qualified (Teske \& Wooldridge 2001, Quintino et al. 2006). On the one hand, estuaries are known to be high productivity regions which support a large abundance and biomass of amongst others macrobenthic fauna (Costanza et al. 1997, Ysebaert et al. 1998, Beck et al. 2001). On the other hand, estuaries are very dynamic systems, and in fluctuating abiotic conditions, species numbers are lower (Sanders 1968, Ysebaert et al. 1998, Dauvin 2007). Closed systems are more vulnerable to eutrophication and pollutants (Petersen et al. 2008, Wijnhoven 
et al. 2010) but provide more opportunities for regulation of the abiotic conditions to improve water quality and reduce risks of certain species becoming pests (West \& West 2007).

Over the last decades, appreciation of the value of 'more natural' systems has intensified. It would however be good to understand the difference between a 'more natural' system (i.e. open system) and a closed system, from a macrobenthic point of view. How do the systems score in terms of macrobenthic indicators, and what happens during the transition from the one system into another? In the present day, plans to re-open previously closed systems are popular (Shaffer et al. 2008, Wijnhoven et al. 2010). Whereas economic and safety objectives used to be the motivation to close sea arms, nature values are now of increasing importance. The water exchange of confined systems is increased, with the ultimate goal of whole estuary restoration. The first step in this direction of restoration is planned for a part of the region known as Delta area, the former 'Rhine-Meuse estuary', situated in the south-western part of the Netherlands (Wijnhoven et al. 2008). It is planned, although currently postponed, to change the sluice regime, which during the last $40 \mathrm{yr}$ allowed for only the outflow of fresh water from the Haringvliet basin into the coastal region 'Voordelta' of the North Sea, such that salt water can intrude inland again. Although salt intrusion will at first only be allowed for $11.5 \mathrm{~km}$, this management action can mean a restoration of the free estuarine salinity gradient in the region. In this context it will be valuable to know how macrobenthic communities react to elementary changes in the constitution of their environment, and what the implications will be for several macrobenthic community descriptors that often used as environmental indicators.

Extensive monitoring of the macrobenthic communities of the Rhine-Meuse estuary has taken place during the transition over the last $50 \mathrm{yr}$ from an estuary into a series of stagnant waters and river branches without open sea influences. Wijnhoven et al. (2008) showed the general developments in abiotic conditions in the presently fresh water part of the region, together with the subsequent differences in macrozoobenthos densities, species numbers and diversity through time. In addition to the study by Wijnhoven et al. (2008), we obtained data from older studies (see 'Materials and methods'), enabling us to close the gap between the developments during the 1960s and 1970s and the recent species assemblage, and to include developments in the current salt water region. The present study shows the value of an extensive long-term dataset for determining the long-term effects of damming an estuary on macrozoobenthic communities. This is essential information from an effectmonitoring point of view. We discuss the usefulness of historic, although to a certain extent deteriorated, communities as reference for the restored situation, as well as data availability, preferable monitoring intensity, and the implications for system evaluation on the basis of macrozoobenthic communities. The aim of the analyses is to extract the general patterns in responses of macrozoobenthic communities to typical changes in the environment that co-occur with transitions from estuarine conditions to stagnant fresh water. Since the study deals with the same area that is now planned to be partly restored towards its original estuarine dynamics, community descriptors will be compared between the historic and the present situation to clarify differences in the natural value of the 2 situations. Future perspectives for the region are identified.

\section{MATERIALS AND METHODS}

\section{Research area and history}

The research area of the Rhine-Meuse estuary (Fig. 1) is situated in the south-western part of the Netherlands and can be divided into 5 main areas, hereafter called basins. From west to east there are: (1) the Voordelta (VD), which is a coastal part of the Dutch North Sea, west of the Haringvliet dam; (2) the Haringvliet (HV), formerly a brackish sea-arm, that has been a large freshwater body since the closing of the large dams build between 1958 and 1968; (3) the Hollandsch Diep (HD), east of the Haringvliet bridge and, since 1969, disconnected from the marine Oosterschelde by the Volkerak dam; $(4)$ the Biesbosch (BB), a former tidal freshwater region consisting of channels and creeks, situated between 2 river arms (Amer and Nieuwe Merwede), and a smaller part situated north of the most eastern part of the Hollandsch Diep; (5) the Rivers (RIV), a combination of all the larger river arms in the south-western part of the Netherlands, extending over an area of $85 \times 30 \mathrm{~km}$. For community analyzing purposes, the basins are sub-divided into regions. The Voordelta is sub-divided into a western and an eastern part (VD1 and VD2, respectively). In a similar way, the Hollandsch Diep is divided into 2, the Biesbosch into 3 and the Haringvliet into 5 regions, and the Rivers basin is sub-divided into the separate main branches and rivers as shown in Wijnhoven et al. (2008).

Following a flooding disaster in 1953, several sea arms in the south-western part of the Netherlands were closed. Among those, the Rhine-Meuse estuary 


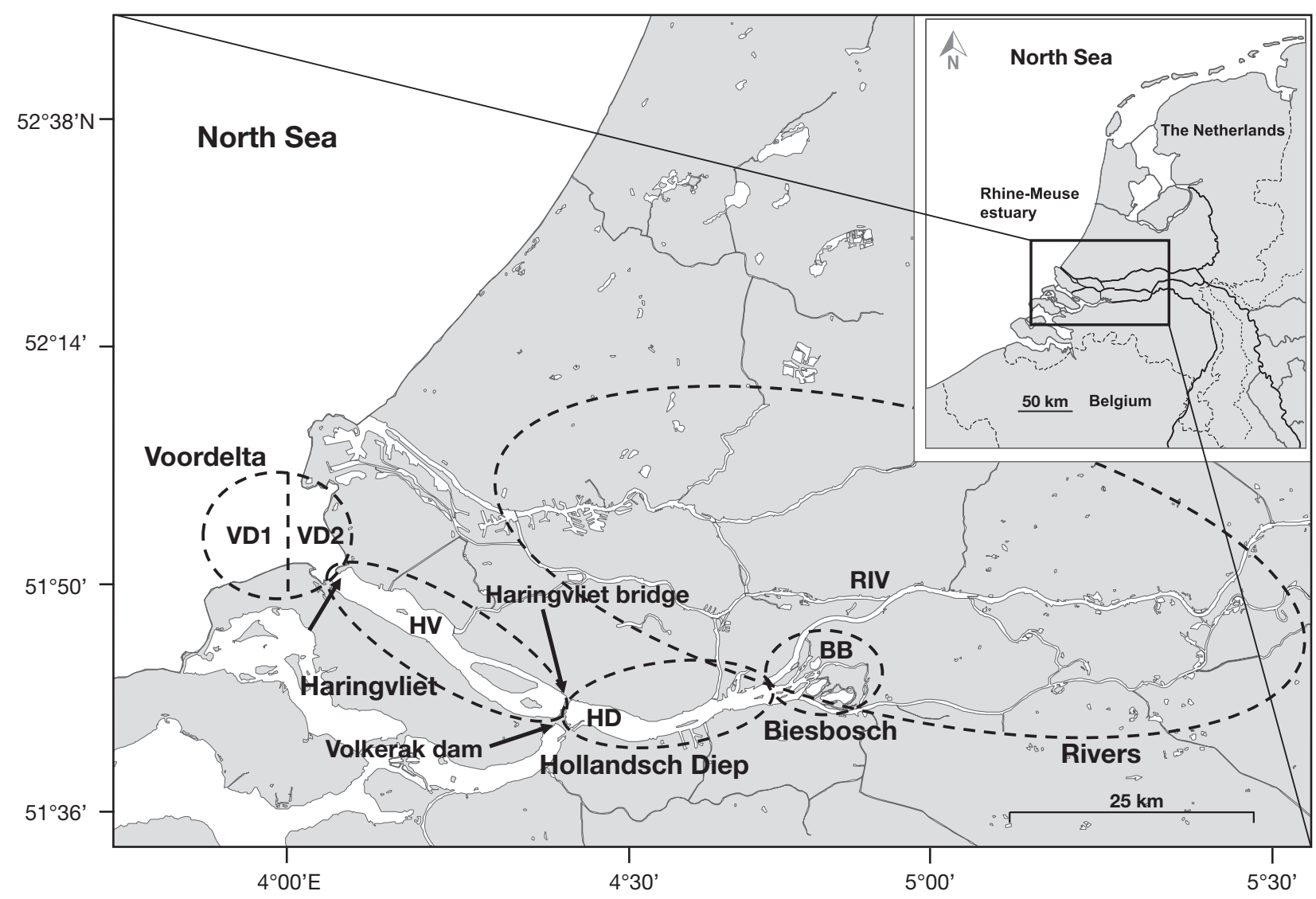

Fig. 1. The Rhine-Meuse estuary in the Netherlands. The research area was divided into 5 basins: the Voordelta, a part of the North Sea coastal zone, in this study subdivided into a western (VD1) and an eastern (VD2) part; the larger water body Haringvliet (HV); the larger water body Hollandsch Diep (HD); the Biesbosch (BB), an area consisting of 'natural' canals and creeks; and the Rivers (RIV; exclusive of BB), a diverse aggregation of larger river branches which belong to the rivers Rhine and Meuse

used to have a full salinity gradient, from the open sea to fresh water with a tidal regime. In 1958, the building of a dam with sluices (Haringvliet dam) began between the Haringvliet and the Voordelta. In 1965 and 1968, 2 smaller inlets (Zuiderdiep and Gat bij NoordPampus, respectively) at the south side of the new dam were closed. In 1968, the Haringvliet dam was finished, and at that time, 34 sluices with an aggregated width of $1 \mathrm{~km}$ remained open. In 1969, the Volkerak dam was finished and closed the connection of the Haringvliet-Hollandsch Diep with the sea to the south. At the end of 1970, a new sluice regime of partially open during low tide and closed during high tide was installed to allow for fresh water release yet block salt intrusion. During the 1990s, plans were launched to restore, amongst others, the Rhine-Meuse estuary (Wijnhoven et al. 2008). The restoration has currently been postponed 3 times, the last time at the end of 2010 with the change of the government. There are, however, plans to change the sluice regimes in the future in such a way that salt water is let in but not further than $11.5 \mathrm{~km}$ inland to safeguard fresh water use for agriculture on the mainland (e.g. www.zuid-holland.nl/ kierbesluit and www.rijkswaterstaat.nl/water).

\section{Data availability and collection}

The macrozoobenthic data used in this study originated from 2 large data sets, which are combined. The first set of data was extracted from the Benthos Information System of the Monitor Taskforce and covers all the verified and validated information held at the NIOO-CEME (and its precursors) for macrobenthic and environmental samples collected in the research area. This dataset is described in more detail in Wijnhoven et al. (2008). The second dataset was compiled to develop a methodology to evaluate the status of tidal freshwaters by means of macrofauna. Only the samples from soft substrates were considered. These data 
were largely collected in projects for the Directorate General of the Dutch Ministry of Infrastructural Planning and Waterworks (RWS) and kindly made available for the current study by the RWS Water Service 'Waterdienst'. This set is described in more detail in Peeters et al. (2008b). The macrozoobenthic samples were obtained with a variety of techniques using boxcorers, grabs, handcorers, handnets, and flushing samplers. The dominant sampling device throughout the dataset was a $0.1 \mathrm{~m}^{2}$ 'van Veen' grab. Most of the samples were sieved through a $1 \mathrm{~mm}$ mesh and fixed with 4 to $6 \%$ buffered formalin. During a few campaigns, however, a $0.5 \mathrm{~mm}$ mesh was used and handnets had a mesh of $0.5 \mathrm{~mm}$. To make the data comparable, all collected macrofauna numbers were standardized to densities (no. $\mathrm{m}^{-2}$ ). This methodology will to some extent have affected the observed assemblages as samples were of various sizes (surface areas) and collected from various depths, which affects the probability of sampling certain species. It is assumed that possible differences in assemblages due to methodology are minor compared to changes in assemblages as a result of changes in the underwater environment of the basins. The final dataset consisted of 5314 macrozoobenthos samples collected between 1960 and 2006.

The abiotic data are kindly made available by the RWS Waterdienst and largely available via www. waterbase.nl. They consist of frequent measurements at fixed stations through time, which are combined in this study per basin. For analyses of salinity, secchi depth (dm), ammonium ( $\mathrm{mg} \mathrm{N}^{-1}$ ) and cadmium $\left(\mu \mathrm{g} \mathrm{l}^{-1}\right), 2880,1193,1905$ and 521 surface water measurements, respectively, were available. Trends in abiotic parameters were visualized per basin by defining the least squared polynomial trend line of the lowest order (preferentially, 2nd over 3rd, 4th, and 5th). The developments in several abiotic parameters are shown for the Haringvliet-Hollandsch Diep-Biesbosch area as a whole in Wijnhoven et al. (2008).

\section{Data standardization and statistics}

Datasets were checked for used synonyms in species names. Incomplete determinations were either deleted (disadvantage is loss of data) or scaled back to a higher level (disadvantage is loss of diversity within the data), dependent on the judged loss of information. Each species, or other taxonomic endpoint level, was categorized to one or more feeding guilds: suspension feeder $(\mathrm{SF})$, deposit feeder (DF), surface deposit feeder (SDF), herbivore $(\mathrm{H})$, predator $(\mathrm{P})$ and omnivore $(\mathrm{O})$. Filter feeders are included in the suspension feeder group, as their ecological preferences do not differ in general (Lavaleye et al. 2007). The deposit feeder group represents the mainly subsurface dwelling deposit feeders, as the surface deposit feeders are distinguished as a separate group. The predator group includes scavengers. For several taxonomical groups the information in the literature is not consistent, or species are known to feed facultatively according to 2 or more mechanisms. To analyze the relative importance of feeding guilds in certain communities, specimens were scored as representatives of one feeding guild, or as 0.5 representatives of 2 feeding guilds, or in some cases as 0.33 representatives of 3 feeding guilds. Information on feeding guilds was largely extracted from Wolff (1973) and the websites www.marinespecies.org and www.marlin.ac.uk.

Macrofauna data were combined with temporal and spatial information and species information in Microsoft Office Access 2003, after which selections were transferred to Microsoft Office Excel 2003 for basic calculations. Spatial information includes a unique sample code, the distribution in basins and regions as described before, and the depth classified into 4 strata (0-2 m, 2-5 m, 5-10 m, and >10 m). Temporal information includes the sample date and the season: winter, spring, summer and autumn, which are respectively formed by samples from the periods December to February, March to May, June to August, and September to November. Sample years are further aggregated into periods: the start of the construction works at the Haringvliet dam (Period A, 1960-1964), the closure of several connections between the sea and the inland waters (Period B, 1965-1970), the transition after blocking the salt water inflow (Period C, 1971-1990), and the relatively more stable periods since 1990 which were split into 3 periods (Period D, 1991-1995, Period E, 1996-2000, and Period F, 2001-2006) due to the large data availability.

Besides the total macrofauna densities (no. $\mathrm{m}^{-2}$ ), the macrofauna indicator species richness according to Margalef's $d$, species diversity according to ShannonWiener index $\left(H^{\prime}\right)$ and evenness according to Pielou's equitability index $\left(J^{\prime}\right)$ were calculated respectively according to $d=(\mathrm{S}-1) / \ln (n), H^{\prime}=-\sum \mathrm{p}_{i} \ln \left(\mathrm{p}_{i}\right)$ and $J^{\prime}=$ $H^{\prime} / \ln (S)$, where $S$ is the number of species per $\mathrm{m}^{2}, n$ equals the number of specimens per $\mathrm{m}^{2}$, and $\mathrm{p}_{i}$ is the proportion of species $i$ in the sample. The macrofauna indicators were calculated using Primer for Windows (version 5.2.8). To calculate average evenness and diversity for certain aggregations, the evenness and diversity was set to 0 when only one species was present in a sample. Also communities were compared on a species density basis using non-metric multi- 
dimensional scaling (nMDS) in combination with analyses of similarity (ANOSIM) executed in Primer v5. Before analyses, all data were fourth-root transformed to minimize the effect of dominant species, and similarity analyses are based on the Bray-Curtis formula (Clarke \& Gorley 2001). The nMDS 2D representations were considered acceptable when the stress factor did not transgress 0.2. With ANOSIM, pair-wise comparisons of groups or aggregations tested for differences at $\mathrm{p} \leq 0.05$. As this often means multiple testing, Bonferroni correction according to $\mathrm{p} \leq 0.05 / \mathrm{N}$, where $\mathrm{N}$ is the number of tests within a group of tests of the same kind, was applied. Primer v5 is restricted to an input spreadsheet of approx. 250 columns, and the limits were reached for the analyses of the basin Rivers (more than 250 species present). Therefore, species present in only 1 or 2 samples of the complete dataset were excluded, bringing the number of species to a manageable 214. To visualize certain aggregations, specific communities including the ones transferred to new analyses and the communities of specific periods were encircled with ovals in the presented nMDS plots (see Fig. 4). These ovals include all aggregations of a certain period, except for a possible singular outlier. To define a potential reference community for each basin, the average community was calculated from the aggregations being encircled in the large plots of Fig. 4 including the oldest aggregations (except for a possible singular outlier), which were $\leq 1968$ for VD, $\leq 1969$ for $H V, \leq 1966$ for $\mathrm{HD}$ and BB, and $\leq 1971$ for RIV. For VD, 2 clearly separated historic communities appeared. The species assemblages of the historic communities were compared with the present situation, which was represented by the average of the most recent samples per basin: 2005-2006 for VD, 2003 and 2005 for HV, 2002 for HD, 2001-2002 for BB, and 2003-2004 for RIV. The utility of the defined historic communities as reference communities for an estuarine situation will be discussed taking the observed species diversity and relative dominance by species and/or taxonomic groups into account. To compare the overall diversity of historic and present communities, it was essential that similar time periods, spatial ranges, and sample numbers be compared. For that purpose $10 \mathrm{yr}$ periods, 1960 to 1969 representing the historic communities and 1997 to 2006 representing the present communities, were compared by analyzing community similarities for aggregates based on 10 randomly taken samples for each of the basin by period combinations. The total diversity of both the historic and present situation (combining the randomly compiled communities of the basins) was determined and tested ( $F$ - and $t$-test) by using average similarity (Bray-Curtis) as a proxy. To indicate the reliability, 10 random compilations were compared. These random compilations can also be used to estimate the total number of species for the entire system (total system species richness) by constructing rarefaction curves to determine the approximate maximum value. We defined the maximum value to be reached when more than 10 extra random aggregations (equals 50 samples) are necessary to find one more species. Differences in total species richness between the historic and present situation were tested using a paired $t$-test.

\section{RESULTS}

\section{Abiotic trends}

At the time of the research area being an open estuary, a full salinity gradient from salt to fresh water was present. Salinity used to be comparable in the Haringvliet (HV) and Hollandsch Diep (HD) basins due to 2 connections (a western and a southern) to the open sea. During the construction works between 1960 and 1970, salt intrusion inland was gradually reduced by the obstruction of the currents as shown in Fig. 2a. This led to a strong decrease in salinity in the Haringvliet and the Hollandsch Diep. The salinity in the Biesbosch (BB) was already in the fresh water range before the construction works, although some periodic salt influences must have been present before 1970 (Vaas 1961, Wolff 1973). After the start of the new sluice regime at the end of 1970, the waters east of the Haringvliet dam could be considered fresh; not only had the salinity decreased in these parts, but salinity variation had become minimal. Furthermore, the salinity in the Voordelta has decreased throughout the last $45 \mathrm{yr}$ as a result of a shift of the salt to freshwater transition to the west. Another strong effect of building the dams has been on the tidal amplitude, which used to be almost $2 \mathrm{~m}$ (Wolff 1973). The tides disappeared, and differences in water levels were driven by wind force, the sluice regime, and altering river outflow and reduced to $0.3 \mathrm{~m}$ in the Haringvliet and Hollandsch Diep and 0.35 to $0.55 \mathrm{~m}$ in the Biesbosch (Backx et al. 2002, Boudewijn et al. 2004). Although no detailed information on the historic situation is available, it is very likely that current velocities were reduced in the Haringvliet and the Hollandsch Diep after the construction of the dam, and they may have increased at the west side of the Haringviet dam in the Voordelta. Due to these changes in current velocities, the sedimentation zone has moved from the Biesbosch to the Hollandsch Diep and the Haringvliet. On the one hand, this can explain 

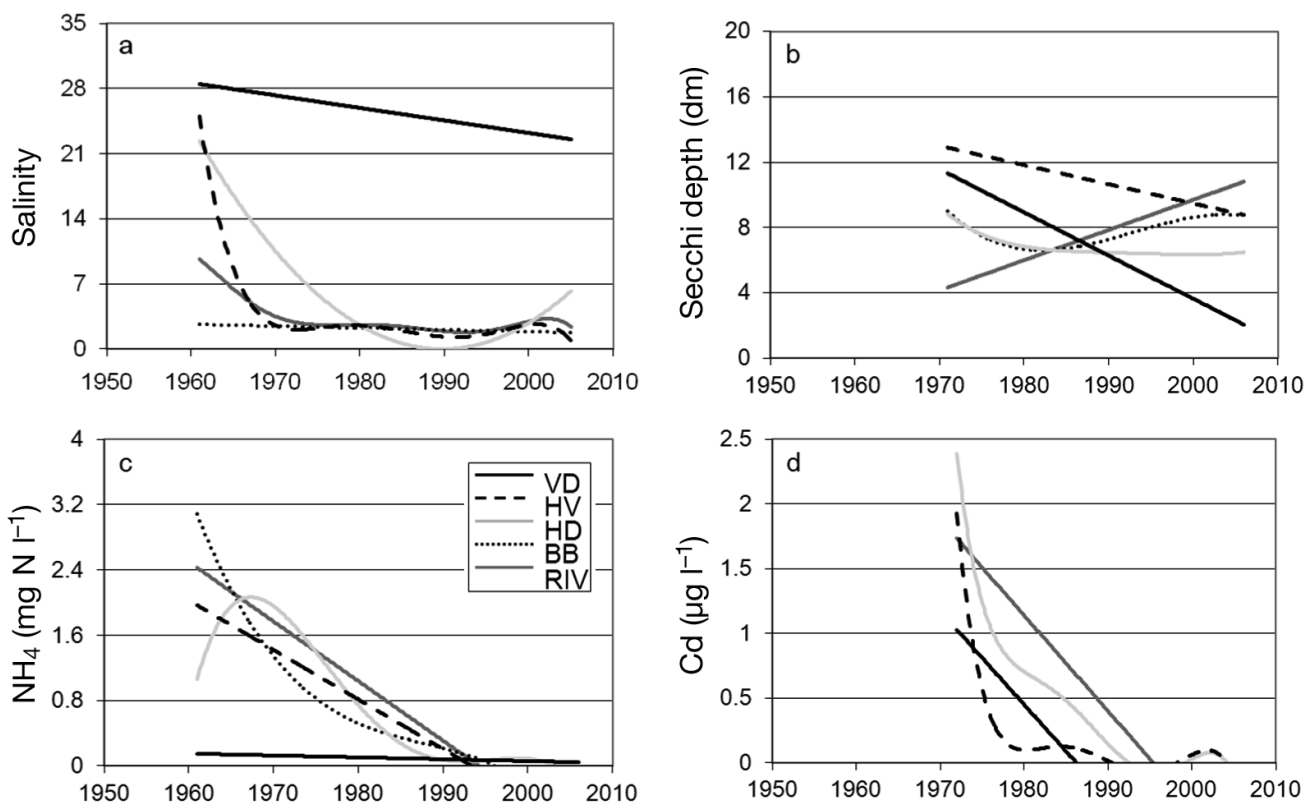

Fig. 2. Changes over time of some abiotic parameters in the basins Voordelta (VD), Haringvliet (HV), Hollandsch Diep (HD), Biesbosch (BB) and the Rivers (RIV) as shown by 3rd to 6th order polygons (as least squared fits through measurements from several stations spread over the basins; polygon order is dependent on whether or not the fit significantly improves with increasing order): (a) salinity; (b) water clearance as secchi disc visibility in $\mathrm{dm}_{i}$ (c) ammonium in $\mathrm{mg} \mathrm{N} \mathrm{l}^{-1}$, as an example of nutrient status;

(d) cadmium in $\mu \mathrm{g} \mathrm{l}^{-1}$, as an example of pollutant status

the reduction of the water clearance in the Haringvliet and the improvement of the secchi depth in the Biesbosch (Fig. 2b). On the other hand, the quality of the supplied river water, especially in terms of the nutrient loads, shown for example by the ammonium concentrations in Fig. 2c, has improved significantly, leading to a reduction in chlorophyll concentrations, particularly on the east side of the research area. The reduction in secchi depth in the Voordelta is probably related to increased turbulence and flocculation as a result of mixing fresh and salt water. Since the early 1970s, the water quality in the entire research area improved significantly in terms of pollutants, as shown by cadmium concentrations (Fig. 2d). For macrozoobenthos, pollutant concentrations in sediments are at least equally important. Also in the sediments, the pollutant concentrations gradually decreased, but compared to the water column with some delay caused by mixture, dilution, and erosion processes. The trends of cadmium are representative for most heavy metals. The concentrations of other substances might still be problematic in some parts of the research area, e.g. tributyltin levels in the sediments of the Biesbosch.

\section{Responses in macrozoobenthos descriptors}

Following the start of the construction works concerning the Haringvliet dam during the early 1960s, the macrozoobenthic densities fluctuated in each of the basins (Fig. 3a). During this decade, the seaward basins showed the largest fluctuations, whereas there was only one broad peak for the Biesbosch and the Rivers. Although 2 peaks in densities can be observed going from the early 1960 s to the early 1970 s for the basins with sufficient sample frequency, the patterns are generally not significant (Table S1 in the supplement at www.int-res.com/articles/suppl/m436p029_ supp.pdf). During the early 1970s, total densities were low. After the 1970s, densities increased in the Haringvliet and the Hollandsch Diep, followed by high densities during the end of the 1980s and 1990s. This might be a typical pattern for all basins, as densities were generally significantly higher during the 1990s, early 2000s, and for the Voordelta also the 1980s, than during the 1960s and 1970s (Fig. 3a, Table S1). The density levels during the last period (Period $F$, 2001-2006) seem to be slightly reduced compared to the levels in the previous $15 \mathrm{yr}$, and the difference is significant in several cases (year-to-year comparisons) for the Voordelta and the Haringvliet (Table S1).

Also the species richness indicated by Margalef's $d$ index (Fig. 3b) and Shannon-Wiener diversity index (Fig. 3c) was rather variable in the 1960s and 1970s and showed increases and decreases in different years for the investigated basins. At least some of the fluctuations in richness and diversity during the 1960s and early 1970s showed the opposite pattern in densities as 

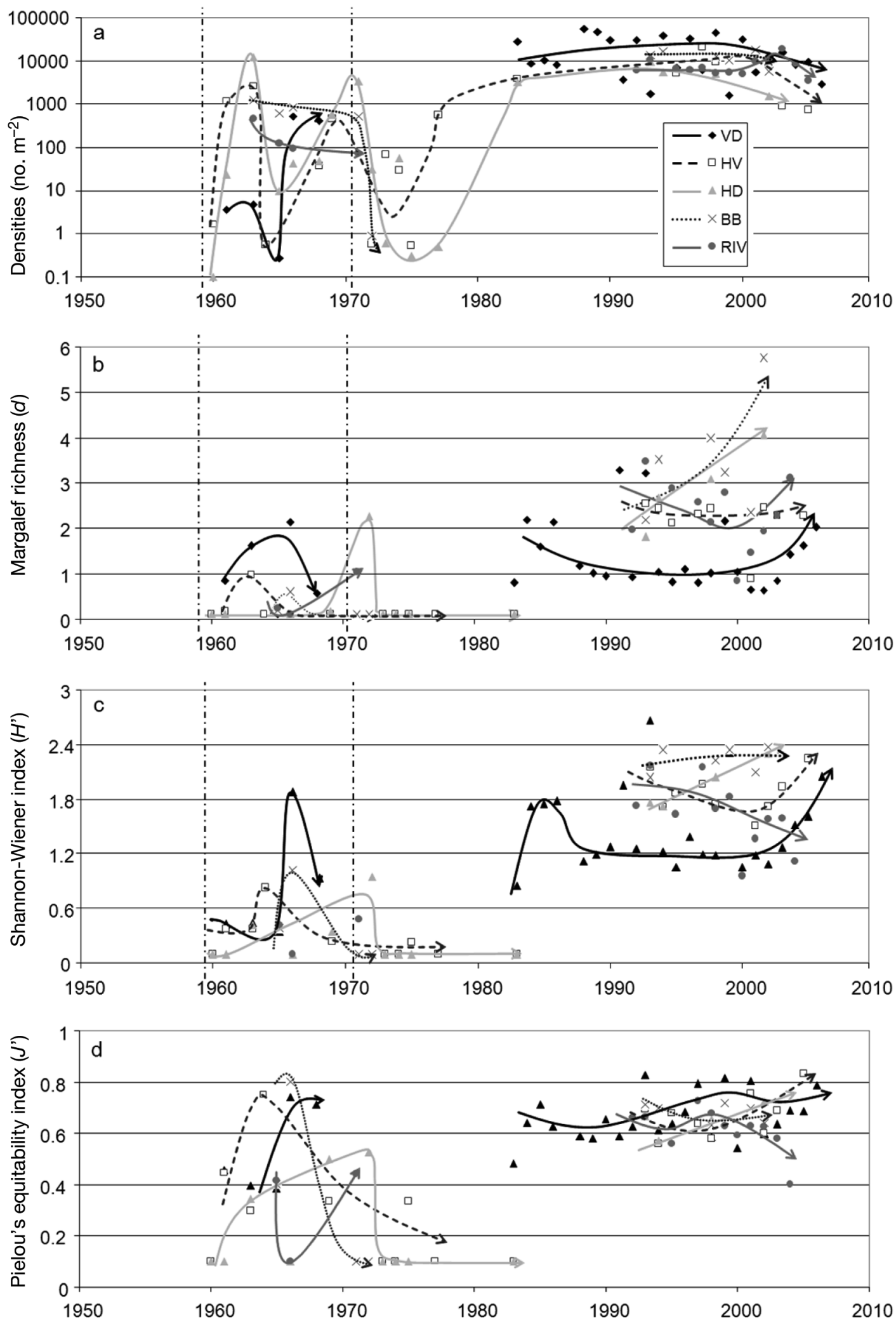

Fig. 3. Changes between 1960 and 2006 in (a) the average density (no. individuals $\mathrm{m}^{-2}$ ) per year, (b) Maragalef richness $d$, (c) Shannon-Wiener index $H^{\prime}$ and (d) Pielou's equitability index $J^{\prime}$, for the 5 basins: Haringvliet Voordelta (VD), Haringvliet (HV), Hollandsch Diep (HD), Biesbosch (BB) and the Rivers (RIV). The onset of the construction works in the region and the start of the Haringvliet dam sluices regime preventing salt water inflow are indicated with vertical dash-dot lines 
indicated by the timing of the peaks (Fig. 3). Again, not all these fluctuations were significant, but significant peaks in richness were observed in the 3 most seaward basins (VD, HV and HD), and significant peaks in diversity were found during this period in the Voordelta, the Hollandsch Diep and the Biesbosch. In general the richness in the 1980s and 1990s was higher, with a further increase in richness during the last period (2001-2006), which is significant for the Voordelta and the Biesbosch. The reduction in densities during the last years of monitoring, particularly in the Voordelta and Haringvliet, co-occured with increases in species richness, relatively stable or increasing evenness, and stable or increasing diversity (Fig. 3, Table S1). A similar pattern can be observed for the Hollandsch Diep. In the Haringvliet, the evenness was significantly lower in 1963 than during the rest of the 1960s (Table S1). Pielou's equitability index (Fig. 3d) strongly fluctuated during the 1960s and 1970s, whereas from the 1980s it stabilized and showed strong similarities in the different basins. The macrobenthic communities of the Rivers with decreasing evenness and diversity showed the opposite pattern to that in the 3 most western basins, and the communities of the Biesbosch showed a pattern in between. The current dataset lacks monitoring data for the second half of the 1970s and the first half of the 1980s. The trends for each of the community descriptors still showed fluctuations during the early 1970s and indicated that at the end of the 1980s some kind of stabilization, generally at a higher level, had occurred.

\section{Community analyses}

The (dis-)similarities and developments of the communities are described for each basin along aggregates of each year by each region by each stratum of which samples are available. Whereas on first sight there is quite some variance in the communities of certain periods (Fig. 4), the insets in Fig. 4, which show community changes through time, illustrate that the variance between distinct periods is much smaller. Comparing the grouping of communities classified per
Fig. 4. Non-metric multi-dimensional scaling (MDS) plots of the community data based on densities for aggregations per year by region by season by stratum for (a) the Haringvliet Voordelta, (b) Haringvliet, (c) Hollandsch Diep, (d) Biesbosch, and (e) Rivers. Potential reference communities for the situation before the dam construction works are indicated with solid ovals; the present situation is indicated with dashed ovals. The community changes through time as indicated by the assemblages during each period are indicated for each basin in the insets (the trend is indicated by the black line ending in an arrow). Period A (grey dotted ovals at base of black trend lines), 1960 to 1964; Period B (grey dotted ovals), 1965 to 1969; Period C (grey short dashed ovals), 1971 to 1990; Period D (grey dash-dotted ovals), 1991 to 1995; Period E (grey long dashed ovals), 1996 to 2000; Period F (grey solid ovals), 2001 to 2006. Analyses of similarity (ANOSIM) test results for the different aggregations are shown in Table 1
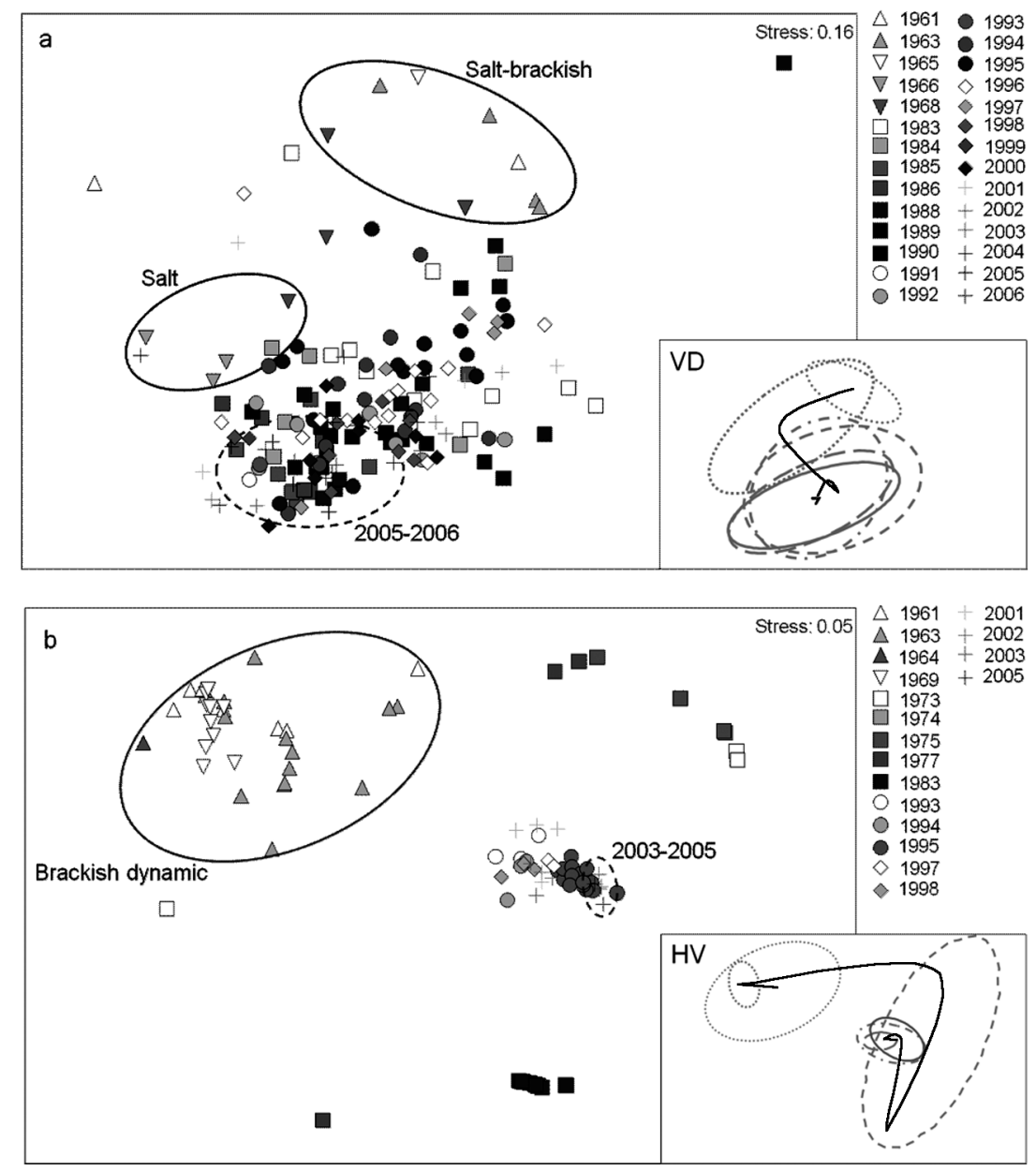
region, stratum or season, significant differences between the classes were found, which were smaller than the differences observed between periods (as indicated by the ANOSIM test results of Table 1 ). The 2 regions within the Voordelta and the various regions of the Rivers explained similar amounts of variability among the communities of these basins as the periods.
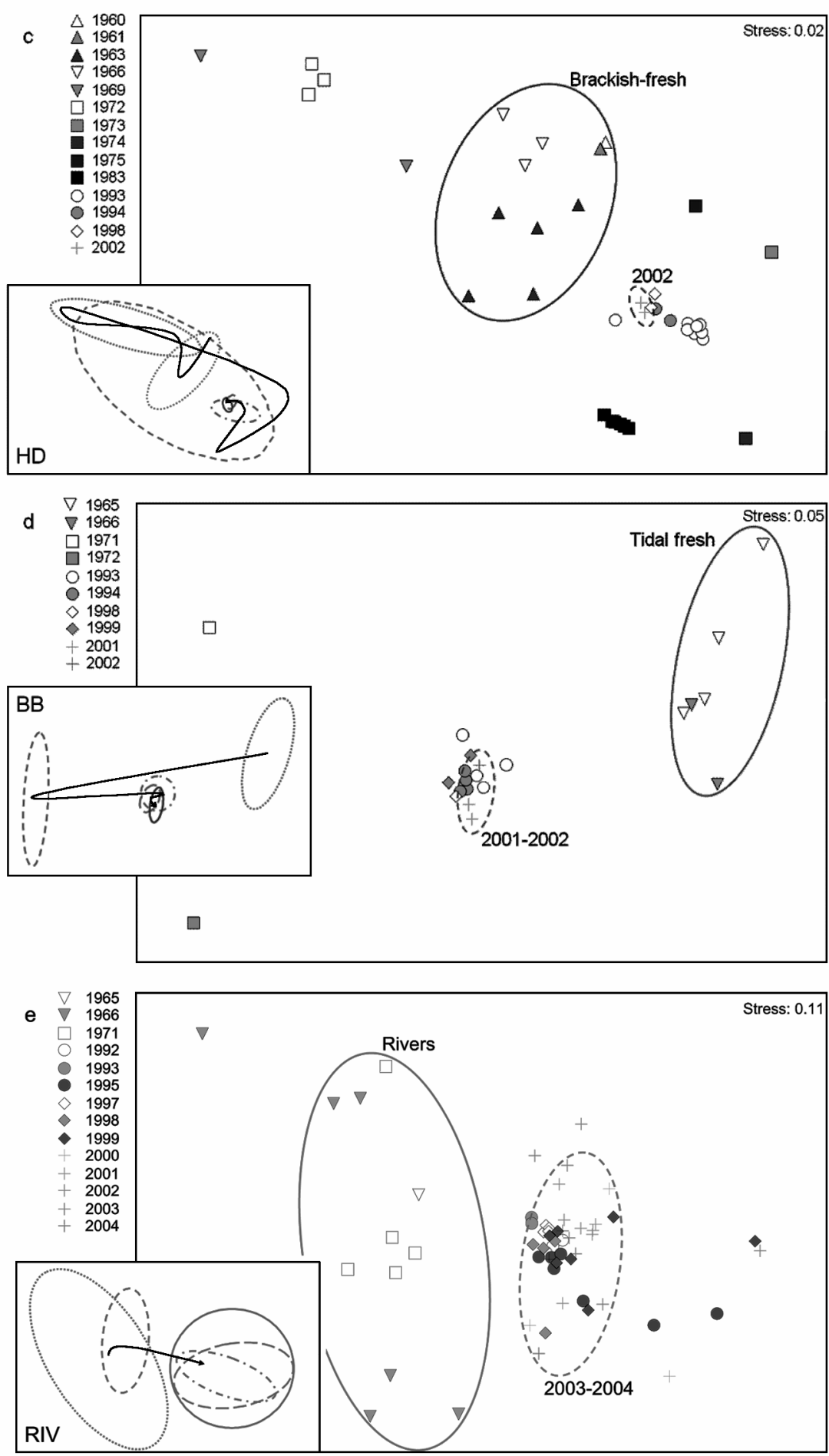

Fig. 4 (continued)
Autumn communities were generally slightly different from those in summer and spring, and the communities of the 2 shallow strata often differed somehow from those of the 2 deeper strata. Since the variability by season and strata was in general less strong (or absent) than for the period (Table 1), we focused in this study on the temporal changes in the assemblages. There is also spatial variability in species assemblages within basins which is, however, not further considered in this study.

The communities of the 1960s looked different, and were significantly different as indicated by the ANOSIM results, from the communities of later periods (Fig. 4a, Table 1). Community changes in the Voordelta were thus largest during the 1960s, and then stabilized to the current situation, although the last period (2001 to 2006) was still significantly different from the communities of all other periods (Table 1). The western half of the Voordelta harbored (especially in the 1960s) a different, more marine, community than the eastern more brackish half (both of a dynamic, relatively shallow, coastal environment), which was taken into account when searching for a possible reference of the situation before the closing of the estuary. In the basins east of the Haringvliet dam, where environmental changes were the largest, the differences between the communities of the various periods were even clearer, as indicated by the R-values (Table 1). In the Haringvliet the changes in communities from the early 1960 s to the end of the 1960s were relatively small (Fig. 4b). But the communities of the 1960s were very different from the communities present during the other periods, and also the 1970s and the 1980s contained distinctive assemblages. The community changes since the early 1990s were only minor. The communities of the 1960s in the Haringvliet were those of a brackish dynamic environment.

First indications of changing communities in the Hollandsch Diep were already visible during the 1960 s, with more marine-brackish characteristics temporarily in 1969 (and 1972) com- 
Table 1. Analyses of similarity (ANOSIM) results corresponding to the non-metric multi-dimensional scaling (nMDS) plots of Fig. 4. (a) Significance (p-values; significant at $p<0.05$; ns = not significant) of distinctions into communities based on either Period, Region, Stratum or Season (aggregation factors) and indicating the degree of separation of aggregated communities with R-values. At $\mathrm{R}=0$, separation is complete between the distinctive communities; at $\mathrm{R}=1$, communities are completely segregated. (b) Significant pair-wise differences between individual time periods (taking a Bonferroni correction into account as indicated with the significance level)

\begin{tabular}{|c|c|c|c|}
\hline (a) Basin & $\begin{array}{l}\text { Aggregation } \\
\text { factor }\end{array}$ & $\mathrm{p}$ & $\mathrm{R}$ \\
\hline Voordelta (VD) & $\begin{array}{l}\text { Period } \\
\text { Region } \\
\text { Stratum } \\
\text { Season }\end{array}$ & $\begin{array}{l}0.001 \\
0.001 \\
0.001 \\
0.001\end{array}$ & $\begin{array}{l}0.220 \\
0.201 \\
0.163 \\
0.160\end{array}$ \\
\hline Haringvliet (HV) & $\begin{array}{l}\text { Period } \\
\text { Region } \\
\text { Stratum } \\
\text { Season }\end{array}$ & $\begin{array}{c}0.001 \\
\mathrm{~ns} \\
0.001 \\
0.002\end{array}$ & $\begin{array}{l}0.521 \\
0.000 \\
0.047 \\
0.130\end{array}$ \\
\hline $\begin{array}{l}\text { Hollandsch Diep } \\
\text { (HD) }\end{array}$ & $\begin{array}{l}\text { Period } \\
\text { Region } \\
\text { Stratum } \\
\text { Season }\end{array}$ & $\begin{array}{c}0.001 \\
\mathrm{~ns} \\
\mathrm{~ns} \\
0.019\end{array}$ & $\begin{array}{l}0.444 \\
0.000 \\
0.020 \\
0.128\end{array}$ \\
\hline Biesbosch (BB) & $\begin{array}{l}\text { Period } \\
\text { Region } \\
\text { Stratum } \\
\text { Season }\end{array}$ & $\begin{array}{c}0.001 \\
\mathrm{~ns} \\
\mathrm{~ns} \\
\mathrm{~ns}\end{array}$ & $\begin{array}{l}0.680 \\
0.000 \\
0.165 \\
0.178\end{array}$ \\
\hline Rivers (RIV) & $\begin{array}{l}\text { Period } \\
\text { Region } \\
\text { Stratum } \\
\text { Season }\end{array}$ & $\begin{array}{c}0.001 \\
0.001 \\
\mathrm{~ns} \\
\mathrm{~ns}\end{array}$ & $\begin{array}{l}0.376 \\
0.392 \\
0.124 \\
0.000\end{array}$ \\
\hline (b) Basin & $\begin{array}{l}\text { Aggregation } \\
\text { factor }\end{array}$ & $\begin{array}{l}\text { Significant } \\
\text { differences }\end{array}$ & $\begin{array}{l}\text { Significance } \\
\text { level }(\alpha)\end{array}$ \\
\hline Voordelta (VD) & Period & $\begin{array}{c}\mathrm{A}-\mathrm{C}, \mathrm{D}, \mathrm{E}, \mathrm{F} \\
\mathrm{B}-\mathrm{C}, \mathrm{D}, \mathrm{E}, \mathrm{F} \\
\mathrm{C}-\mathrm{D}, \mathrm{E}, \mathrm{F} \\
\mathrm{D}-\mathrm{F} \\
\mathrm{E}-\mathrm{F}\end{array}$ & $<0.008$ \\
\hline Haringvliet (HV) & Period & $\begin{array}{c}\mathrm{A}-\mathrm{C}, \mathrm{D}, \mathrm{E}, \mathrm{F} \\
\mathrm{B}-\mathrm{C}, \mathrm{D}, \mathrm{E}, \mathrm{F} \\
\mathrm{C}-\mathrm{D}, \mathrm{F} \\
\mathrm{D}-\mathrm{F}\end{array}$ & $<0.008$ \\
\hline $\begin{array}{l}\text { Hollandsch Diep } \\
\text { (HD) }\end{array}$ & Period & $\begin{array}{c}A-C, D \\
B-C, D \\
C-D\end{array}$ & $<0.008$ \\
\hline Biesbosch (BB) & Period & $\begin{array}{l}B-D \\
C-D\end{array}$ & $<0.01$ \\
\hline Rivers (RIV) & Period & $\begin{array}{l}B-D, E, F \\
C-D, E, F\end{array}$ & $<0.01$ \\
\hline
\end{tabular}

pared to the previously brackish community with fresh water elements beginning in the 1960s (Fig. 4c). The communities of the 1970s and 1980s were significantly different from the previous period, and also differed from the communities of the later periods (1990s and later; Table 1).

The Biesbosch communities of the 1960s were very different from those of the 1970s and from those of the early 1990s (Fig. 4d, Table 1). Since the early 1990s, little has changed in the benthic communities. The communities of the mid 1960s were the best available representation of the historic tidal fresh water communities.

Although the basin Rivers contains a diverse group of environments, clear changes in time were observed (Fig. 4e). The communities of the mid 1960s and the early 1970s did not differ (Table 1), partly due to the large variance between the regions. Yet the communities observed during the 1960s and 1970s were significantly different from the later communities (from the 1990s). The aggregated communities of 1965, 1966 and 1971, except for one outlying aggregation, formed the closest available representation of the historic River communities.

\section{Comparing the present communities with the historic reference}

The historic (1960s) communities of each basin were compared with the most recent community assemblages, represented by aggregates of the last sampling years (indicated in Fig. 4). Comparing the distribution of specimens over the feeding guilds for each of the basins for the historic situation, we found that the suspension feeders were dominant in numbers, followed by the surface deposit feeders, in the Haringvliet, the Hollandsch Diep and the Rivers (Fig. 5). In the salt water community of the Voordelta, these feeding groups were more in balance with abundances of deposit feeders and predators. These last 2 groups were particularly abundant in the historic communities of the salt-brackish Voordelta and the Biesbosch. In the Biesbosch, herbivores were quite numerous, though they were largely lacking in all other basins. While omnivores were generally not very abundant compared to other feeding guilds, the highest number of them occurred in the midrange (HD, HV) of the whole research area.

In the present situation, the distribution of specimens over the feeding guilds is less different between the basins than in the historic situation (Fig. 5). The dominant groups were the suspension feeders followed by the deposit feeders and the surface deposit feeders, often in this order of abundance. Only in the Biesbosch were deposit and surface deposit feeders more abundant than suspension feeders. In the Haringvliet, predators were relatively abundant. Other feeding guilds were always of lesser importance. Only one community was described for the Voordelta, thus VD1 and VD2 were the same.

The community descriptors between the historic and current communities of each of the basins were com- 
Fig. 5. Percentage of specimens over functional feeding groups for (a) the potential reference communities and (b) the communities that can be found at present in each of the basins: Voordelta (VD1 and VD2), Haringvliet (HV), Hollandsch Diep (HD), Biesbosch (BB) and Rivers (RIV). The recognized functional feeding groups are: suspension feeders $(\mathrm{SF})$, deposit feeders (DF), surface deposit feeders $(\mathrm{SDF})$, herbivores $(\mathrm{H})$, predators $(\mathrm{P})$, and omnivores (O). Note that the historic Voordelta is separated into 2 communities, but not in the present situation as no clearly separable communities were observed (the community structure for the whole Voordelta is shown at VD1 and VD2)

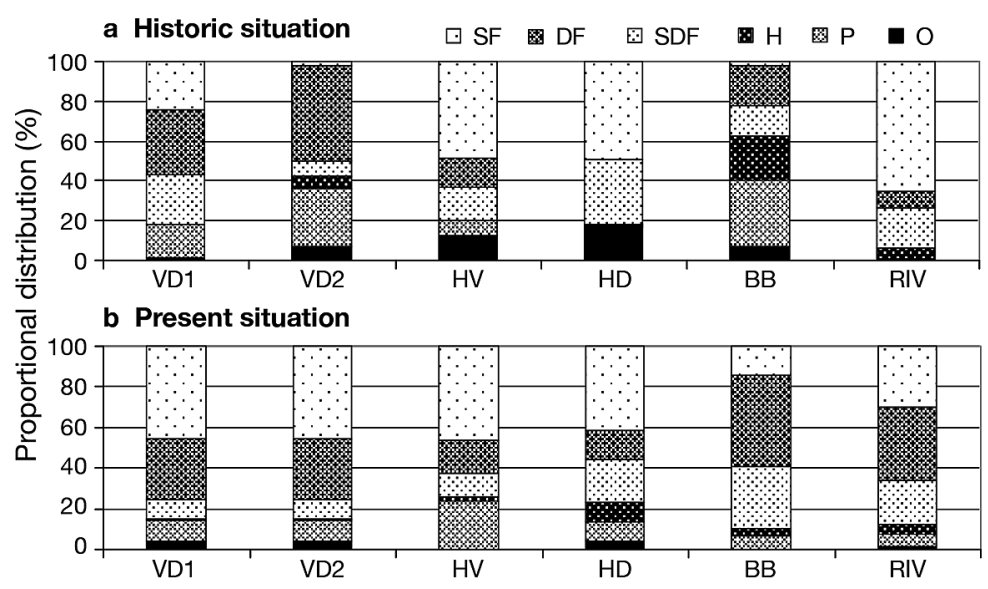

pared (Fig. 6). Where total densities (Fig. 6a) were always high at present, these fluctuated much more between the basins in the historic situation, with particularly low densities in the brackish-salt part of the Voordelta and in the Rivers. The species richness and species diversity, especially for the Haringvliet, Biesbosch and Rivers, were relatively low for the historic communities, whereas, in the recent period, these were high in all basins, with highest values in the Hollandsch Diep (Fig. 6b,c).

The evenness also showed low values in the historic situation (Fig. 6d). In all basins the current evenness was significantly higher than the historic evenness, except for the salt water part of the Voordelta where
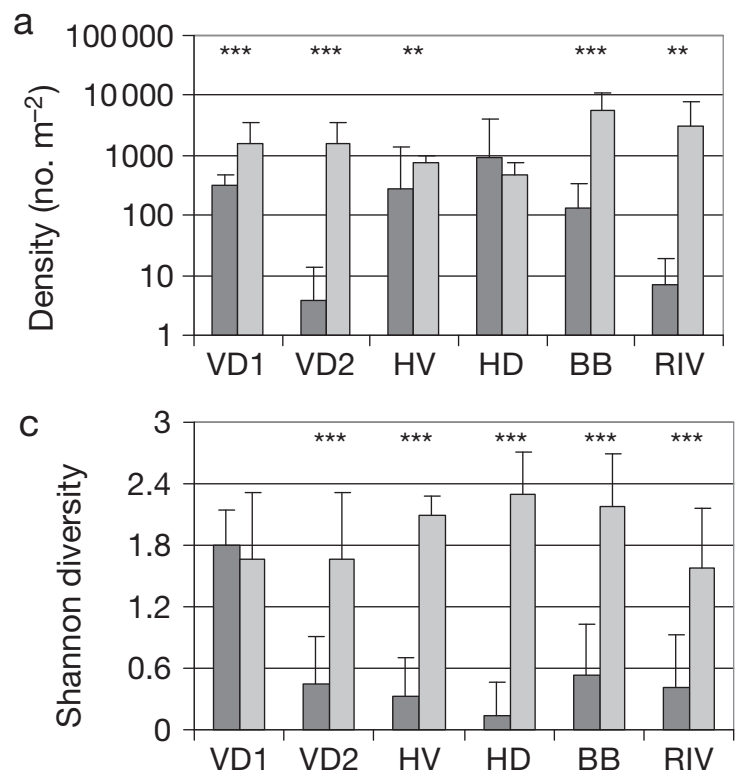

patterns were the opposite. The same patterns observed for evenness were found when species diversity was compared across time.

When all historic and present communities (as indicated in Fig. 4) were plotted on one nMDS graph (Fig. 7), the historic communities showed a clear gradient from VD1 to RIV. This was a gradient from salt water communities through salt-brackish, via the brackish dynamic and brackish-fresh which were more or less the same, to the tidal fresh water communities, and ending with the freshwater communities of the Rivers (Fig. 7). The present communities clustered in one group clearly separated from the historic communities, with the exception of the current Voordelta com-
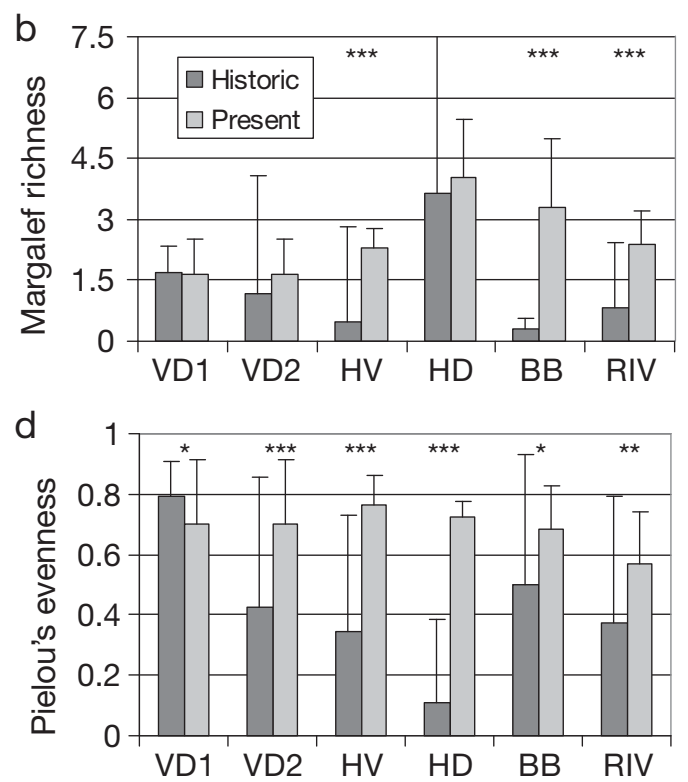

Fig. 6. Comparison of community descriptors between historic (1960s) and present (2000s; see Fig. 4 dashed ovals in large panels for exact years) communities. (a) Macrozoobenthos density (no. individuals $\mathrm{m}^{-2}$ ); (b) Margalef richness $d_{\text {; }}$ (c) Shannon-Wiener index $H^{\prime}$; (d) Pielou's equitability index $J^{\prime}$, for the basins Haringvliet Voordelta (VD1 and VD2), Haringvliet (HV), Hollandsch Diep (HD), Biesbosch (BB) and Rivers (RIV). Significant differences between historic and present communities are indicated with ${ }^{* * *}$ for

$$
\mathrm{p}<0.001 i^{* *} \text { for } \mathrm{p}<0.01 ;{ }^{*} \text { for } \mathrm{p}<0.05
$$




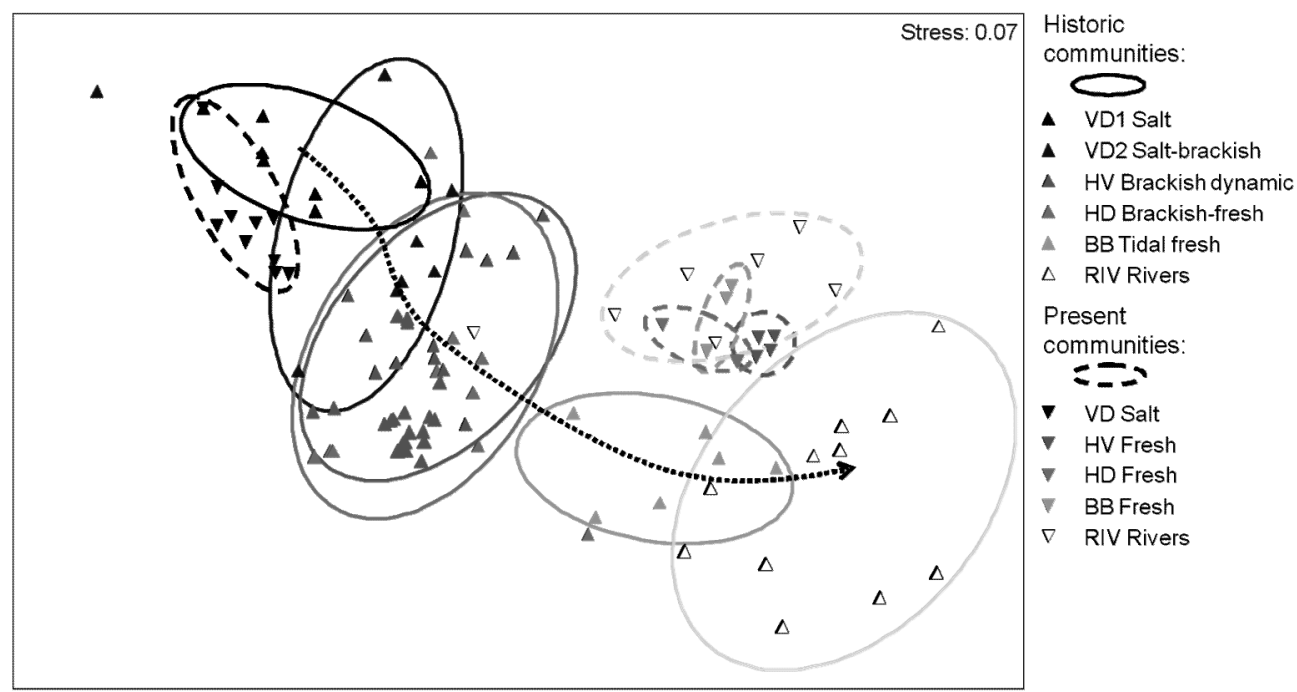

Fig. 7. Non-metric multidimensional scaling (nMDS) plot of the historic and present communities as identified in Fig. 4 for the basins Voordelta (VD1 and VD2), Haringvliet (HV), Hollandsch Diep (HD), Biesbosch (BB) and Rivers (RIV). Corresponding analyses of similarity (ANOSIM) test results are shown in Table 2 munity which was situated near the historic salt water community. The historic and the present Voordelta communities were also significantly different from each other (Table 2). The present communities were therefore separated into a salt water and a fresh water community. Whereas relative differences between community compositions indicated by the centers of the community clouds (and tested using ANOSIM; Table 2) were quite reliable, the variation was highly dependent on the sampling period and the sampling intensity. To determine whether there are possible differences in total diversity for the whole system between the historic and the present situation, similar time-spans (10 yr periods) and sample sizes (by random selection of samples) were used. Fig. 8 gives an overview of the compiled communities based on simi-

Table 2. Analyses of similarity (ANOSIM) test results, corresponding to the non-metric multi-dimensional scaling (nMDS) plots of Fig. 7 indicating the overall significant differences between indentified communities. R-values for pair-wise comparisons between communities vary between 0 and 1 , indicating the degree of separation between distinctive communities at $\mathrm{R}=0$ and complete segregation at $\mathrm{R}=1$, and are shown when significant (with significance level $\alpha=0.005$ after Bonferroni correction; ns $=$ not significant)

\begin{tabular}{|c|c|c|c|c|c|c|c|c|c|c|c|}
\hline & \multicolumn{6}{|c|}{ - Historic - } & \multicolumn{4}{|c|}{ Present -} \\
\hline & & VD1 & VD2 & $\mathrm{HV}$ & HD & $\mathrm{BB}$ & RIV & VD & $\mathrm{HV}$ & HD & BB \\
\hline & VD2 & ns & & \multicolumn{8}{|c|}{ Overall comparison of communities: $p=0.001, R=0.667$} \\
\hline 궁 & $\mathrm{HV}$ & 0.792 & 0.600 & & & & & & & & \\
\hline$\vec{n}$ & HD & 0.583 & ns & ns & & & & & & & \\
\hline 正 & BB & 0.861 & 0.698 & 0.809 & 0.482 & & & & & & \\
\hline \multirow{6}{*}{$\begin{array}{l}0 \\
0 \\
0 \\
0 \\
D \\
D\end{array}$} & RIV & 0.586 & 0.543 & 0.814 & 0.526 & $\mathrm{~ns}$ & & & & & \\
\hline & VD & 0.472 & 0.710 & 0.791 & 0.731 & 0.983 & 0.712 & & & & \\
\hline & $\mathrm{HV}$ & 0.852 & 0.676 & 0.849 & 0.689 & 0.802 & ns & 1.000 & & & \\
\hline & $\mathrm{HD}$ & ns & ns & 0.823 & ns & ns & $\mathrm{ns}$ & ns & ns & & \\
\hline & BB & ns & ns & 0.848 & 0.672 & ns & $\mathrm{ns}$ & 1.000 & ns & ns & \\
\hline & RIV & 0.775 & 0.603 & 0.754 & 0.577 & 0.714 & 0.413 & 0.928 & ns & ns & ns \\
\hline
\end{tabular}

lar sample sizes for similar time-spans for each of the basins during the historic and the present situation. Differences in compiled communities per basin and period were relatively small, indicating that 10 random samples give a good view of the expected average community. The average similarity among compiled communities of the basins for the historic and the present situation differed considerably, as indicated by the 10 random comparisons (Table 3). The similarity is on average more than 2 times larger at present, which indicates that the total diversity at present can be considered more than 2 times smaller than it used to be during the 1960s.

Comparison of the total species richness of the system based on similar sampling intensity and similar spatial and temporal sample distribution (Fig. 9) indicates that, with 3 to 6 compiled sets of samples (that is 150 to 300 samples), the largest part of the total number of species was identified. In the present situation, the species richness in total number of species for the system was much higher with probably about 294 species present, which was significantly higher than the probably about 83 species for the historic situation.

\section{Community composition}

The extracted historic and present communities consisted of sets of species with average densities for each of the communities and a certain chance of presence in a 


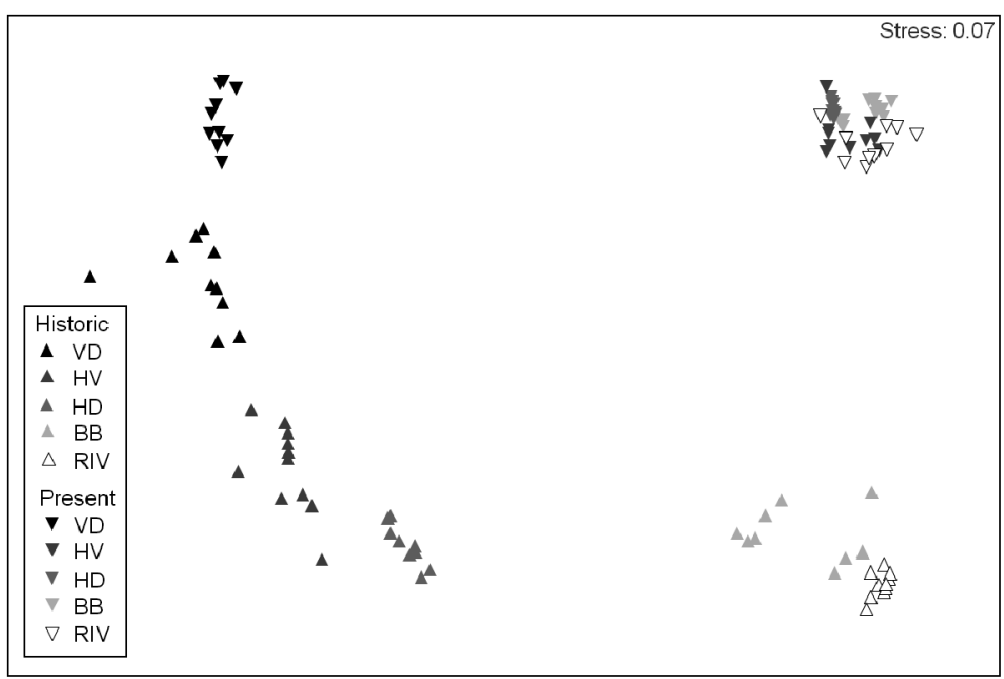

Fig. 8. Non-metric multi-dimensional scaling (nMDS) plot of 10 compiled communities, based on 10 random samples, for each basin (Voordelta, VD; Haringvliet, HV; Hollandsch Diep, HD; Biesbosch, BB; Rivers, RIV) and time period (Historic, 1960 to 1969; Present, 1997 to 2006) combination average density of $<1$ ind. $\mathrm{m}^{-2}$ for Macoma balthic. This was also the most frequently encountered species present in one-third of the samples. Other characteristic species are the polychaete Nereis diversicolor and the mysids Neomysis integer and Crangon crangon. At present, the community of the Voordelta is dominated by the exotic clam Ensis sp., especially E. directus in this region. Other characteristic species are the polychaetes $M$. papillicornis, Nephtys hombergii and Nephtys cirrosa, and the on average very abundant species Tharyx marioni, Lanice conchilega and Urothoe poseidonis (respectively 2 polychaetes and a decapod).

The historic dynamic brackish water community of the Haringvliet was dominated (in terms of average densities and in occurrence) by the polychaete Nereis diversicolor. Also the polychaetes Bocrandom sample. These are respectively indicated as the abundance (no. $\mathrm{m}^{-2}$ ) and occurrence (\%) for the 5 most spatially distributed and 5 most abundant species per community in Table 4.

The historic salt water community of the Voordelta typically contained the polychaetes Spiophanes bombyx, Magelona papillicornis and Nephtys cirrosa. In particular, Scoloplos armiger was relatively abundant (found in about $45.5 \%$ of the samples). In the saltbrackish historic community of the Voordelta, none of the species reached high densities, with the highest

Table 3. Comparisons between the historic and the present situation of the average similarity using $F$ - and $t$-tests among 5 random sets of compiled communities with one set per basin. Bold: significant differences at $p<0.05$. Average similarity can be a proxy for total system diversity with the highest diversity at the lowest similarity. The similarity between random sets of species assemblages per basin for the historic and present situation is visualized in Fig. 8

\begin{tabular}{|lccccc|}
\hline \multirow{2}{*}{$\begin{array}{l}\text { Random } \\
\text { selection }\end{array}$} & \multicolumn{3}{c}{ Himilarity $( \pm \mathrm{SD})$} & & \multicolumn{2}{c|}{ - -value -} \\
\cline { 2 - 3 } & & Present & & $F$-test & $t$-test \\
\hline 1 & $18.96 \pm 18.86$ & $32.15 \pm 27.10$ & 0.295 & 0.111 \\
2 & $13.02 \pm 14.96$ & $29.37 \pm 25.10$ & 0.139 & $\mathbf{0 . 0 4 7}$ \\
3 & $13.40 \pm 15.04$ & $32.86 \pm 28.36$ & & 0.072 & $\mathbf{0 . 0 3 6}$ \\
4 & $18.68 \pm 19.48$ & $32.08 \pm 27.66$ & 0.311 & 0.113 \\
5 & $15.16 \pm 12.01$ & $34.61 \pm 29.89$ & $\mathbf{0 . 0 1 2}$ & $\mathbf{0 . 0 4 0}$ \\
6 & $12.65 \pm 13.69$ & $33.35 \pm 28.91$ & $\mathbf{0 . 0 3 6}$ & $\mathbf{0 . 0 3 1}$ \\
7 & $16.20 \pm 15.58$ & $30.17 \pm 26.31$ & 0.134 & 0.083 \\
8 & $13.74 \pm 15.75$ & $32.92 \pm 28.39$ & 0.094 & $\mathbf{0 . 0 3 9}$ \\
9 & $15.02 \pm 16.56$ & $32.24 \pm 27.89$ & 0.137 & 0.055 \\
10 & $12.72 \pm 17.21$ & $33.05 \pm 28.55$ & 0.147 & $\mathbf{0 . 0 3 5}$ \\
Mean & $14.96 \pm 15.91$ & $32.28 \pm 27.82$ & & \\
\hline
\end{tabular}
cardiella ligerica and Polydora ligni used to be abundant. Further the historic community of the Haringvliet had several abundant species in common with the historic salt-brackish community of the Voordelta. Currently, especially the genera Procladius (insects) and Corbicula (non-indigenous bivalves) are very abundant, and several species of the genus Pisidium (bivalves) are frequently observed. These are all typical freshwater genera, but several species that also occur in brackish waters can be observed as well.

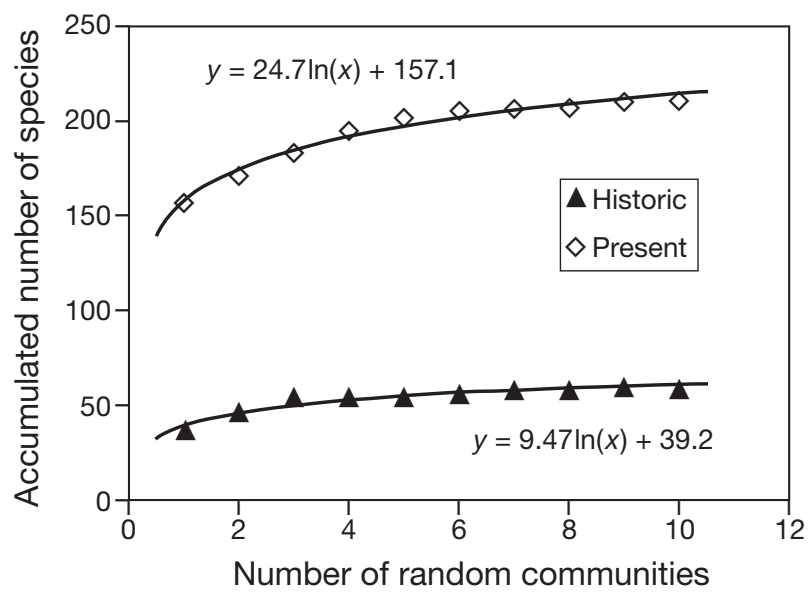

Fig. 9. Rarefaction curves for the historic and present species assemblages based on aggregations existing of 10 random samples for each basin to identify the total number of species in the system and the total species richness of the system. The estimated number of species equals about 225 for the present and about 70 for the historic situation and is significantly different $\left(\mathrm{p}=1.32 \times 10^{-11}\right.$, paired $t$-test) 
Table 4. Composition of the historic and present communities. Indicated are the species belonging to the top 5 most frequently observed (in percentage of samples in which they occur) and top 5 most abundant species (in densities calculated as no. individuals $\mathrm{m}^{-2}$ per basin) for each of the communities identified in Fig. $4 . \mathrm{VD}=$ Voordelta; HV = Haringvliet; HD = Hollandsch Diep; BB = Biesbosch; RIV = Rivers; nemerteans (PH-Nemertea) and nematods (PH-Nematoda) were only identified to the phylum level

\begin{tabular}{|c|c|c|c|c|c|}
\hline Historic communities & $\begin{array}{c}\text { Occurrence } \\
(\%)\end{array}$ & $\begin{array}{l}\text { Abundance } \\
\left(\text { no. } \mathrm{m}^{-2}\right)\end{array}$ & Present communities & $\begin{array}{c}\text { Occurrence } \\
(\%)\end{array}$ & $\begin{array}{l}\text { Abundance } \\
\left(\text { no. }^{-2} \text { ) }\right.\end{array}$ \\
\hline VD1 Salt & & & VD Salt & & \\
\hline Spiophanes bombyx & 90.9 & 90.1 & Ensis sp. & 64.3 & 331.0 \\
\hline Magelona papillicornis & 90.9 & 39.8 & Magelona papillicornis & 60.8 & 106.5 \\
\hline Nephtys cirrosa & 81.8 & 25.7 & Nephtys hombergii & 56.7 & 27.4 \\
\hline PH-Nemertea & 63.6 & 10.6 & Nephtys cirrosa & 56.1 & 31.7 \\
\hline Nephtys hombergii & 63.6 & 9.16 & Spiophanes bombyx & 53.2 & 33.9 \\
\hline Scoloplos armiger & 45.5 & 48.2 & Urothoe poseidonis & 43.3 & 119.8 \\
\hline Spio martinensis & 45.5 & 15.9 & Lanice conchilega & 42.7 & 123.6 \\
\hline VD2 Salt-brackish & & & Tharyx marioni & 21.1 & 152.7 \\
\hline Macoma balthica & 33.3 & 0.94 & & & \\
\hline Nereis diversicolor & 28.2 & 0.023 & & & \\
\hline Neomysis integer & 23.1 & 0.54 & & & \\
\hline Crangon crangon & 17.9 & 0.52 & & & \\
\hline Bathyporeia pilosa & 17.9 & 0.28 & & & \\
\hline Capitella capitata & 15.3 & 0.29 & & & \\
\hline HV Brackish dynamic & & & HV Fresh & & \\
\hline Nereis diversicolor & 75.3 & 69.0 & Procladius sp. & 100 & 172.3 \\
\hline Streblospio shrubsolii & 18.5 & 12.2 & Corbicula sp. & 100 & 128.1 \\
\hline Neomysis integer & 18.5 & 3.46 & Pisidium moitessierianum & 100 & 88.3 \\
\hline Boccardiella ligerica & 17.3 & 90.9 & Pisidium henslowanum & 100 & 49.0 \\
\hline Polydora ligni & 14.8 & 77.0 & Pisidium casertanum & 100 & 35.0 \\
\hline \multirow[t]{4}{*}{ Crangon crangon } & 11.1 & 13.6 & Potamothrix moldaviensis & 100 & 27.3 \\
\hline & & & Branchiura sowerbyi & 100 & 23.2 \\
\hline & & & Limnodrilus hoffmeisteri & 100 & 18.3 \\
\hline & & & Potamopyrgus antipodarum & 66.7 & 76.2 \\
\hline HD Brackish-fresh & & & HD Fresh & & \\
\hline Nereis diversicolor & 50.0 & 302.8 & Potamopyrgus antipodarum & 100 & 77.0 \\
\hline Crangon crangon & 31.8 & 2.74 & Corbicula sp. & 100 & 28.8 \\
\hline Neomysis integer & 13.6 & 4.39 & Hypania invalida & 100 & 23.4 \\
\hline Gammarus zaddachi & 13.6 & 1.36 & Gammarus tigrinus & 100 & 17.0 \\
\hline Boccardiella ligerica & 9.1 & 590.9 & Limnomysis benedeni & 100 & 13.4 \\
\hline Capitella capitata & 9.1 & 0.046 & Jaera istri & 100 & 4.80 \\
\hline \multirow[t]{3}{*}{ Bathyporeia pilosa } & 9.1 & 0.038 & Cladotanytarsus sp. & 80.0 & 55.6 \\
\hline & & & Dreissena polymorpha & 80.0 & 36.8 \\
\hline & & & Valvata piscinalis & 80.0 & 35.6 \\
\hline BB Tidal fresh & & & BB Fresh & & \\
\hline Pisidium amnicum & 65.8 & 33.4 & Einfeldia carbonaria & 81.8 & 1268.0 \\
\hline Pisidium supinum & 44.7 & 16.8 & Valvata piscinalis & 77.3 & 255.4 \\
\hline Gammarus zaddachi & 21.1 & 42.4 & Corbicula sp. & 77.3 & 35.8 \\
\hline Sphaerium solidum & 21.1 & 5.79 & Procladius sp. & 72.7 & 183.1 \\
\hline Pisidium subtruncatum & 21.1 & 3.95 & Pisidium henslowanum & 72.7 & 117.5 \\
\hline \multirow[t]{4}{*}{ Pisidium casertanum } & 10.5 & 18.4 & Polypedilum nubeculosum & 72.7 & 97.3 \\
\hline & & & Cladotanytarsus sp & 63.6 & 577.8 \\
\hline & & & Vejdovskyella intermedia & 59.1 & 1002.4 \\
\hline & & & PH-Nematoda & 54.5 & 251.3 \\
\hline RIV Rivers & & & RIV Rivers & & \\
\hline Pisidium supinum & 44.2 & 0.64 & Corbicula sp. & 60.9 & 304.6 \\
\hline Sphaerium corneum & 25.0 & 1.96 & Cladotanytarsus sp. & 60.9 & 230.3 \\
\hline Chironomus reductus & 19.2 & 0.60 & Potamopyrgus antipodarum & 60.9 & 142.7 \\
\hline Pisidium casertanum & 17.3 & 0.044 & Corophium multisetosum & 52.2 & 175.0 \\
\hline Spisula solida & 15.4 & 0.044 & Valvata piscinalis & 52.2 & 91.6 \\
\hline Pisidium henslowanum & 11.5 & 0.22 & Pisidium moitessierianum & 43.5 & 130.2 \\
\hline Valvata piscinalis & 11.5 & 0.033 & & & \\
\hline
\end{tabular}


The most frequently observed species Nereis diversicolor and Crangon crangon of the historic Hollandsch Diep community also used to be among the common species for the Voordelta and the Haringvliet. In the historic brackish-freshwater environment of the Hollandsch Diep, Boccardiella ligerica used to be very abundant. For the current community of the Hollandsch Diep it is typical that the 6 species or genera found in all samples are non-indigenous, of which Potamopyrgus antipodarum (gastropod), Corbicula sp. and Hypania invalida (polychaete) are most abundant.

The Pisidium species $P$. amnicum and $P$. supinum had the broadest distribution in the historic tidal fresh water communities of the Biesbosch, and also other Pisidium species were common. Further, Gammarus zaddachi (crustacean) and Sphaerium solidum (bivalve) were common, of which G. zaddachi was the most abundant species. In the present situation, under the fresh water conditions without a tide, Einfeldia carbonaria (insect), Valvata piscinalis (gastropod) and Corbicula sp. are frequently found. The tubifex worms (e.g. Vejdovkyella intermedia) and the midge larvae (e.g. Cladotanytarsus sp.) reached very high densities.

The most common historic river species were Pisidium supinum, Sphaerium corneum (gastropod) and Chironomus reductus (insect); now, the genera Corbicula and Cladotanytarsus and Potamopyrgus antipodarum are common and very abundant.

\section{DISCUSSION}

\section{General patterns in indicator development}

The beginning of the construction works between 1958 and 1960 likely led to gradually increasing changes in the abiotic conditions. Currents, tides, salt intrusion, and salinity level and variability decreased, and turbidity and probably nutrient availability increased. These effects were noticeable in each of the basins, leading to permanent changes in the character of the environments. Such major disturbance of the environment leads to the flourishing of opportunistic species as part of early succession. This theory is supported by the peaking total densities during the early 1960s for short periods, co-occurring with low numbers of species and diversity (Fig. 3). In the Haringvliet, Polydora ligni became particularly abundant, and in both Haringvliet and Hollandsch Diep, Boccardiella ligerica densities peaked. The Voordelta might have been influenced the least, as shown by the initially lower increase in densities and the somewhat higher levels in richness and diversity. The initially most disturbing building activi- ties - the building of pillars and dam parts - were finished in the early 1960s. During the following period when sluices and regulation mechanisms were built, the disturbances on the underwater environment were relatively less severe. During that period species densities decreased again, and richness, evenness and diversity improved. A second major disturbance was the definite closing of inlets like the 2 smaller inlets in the west and the southern connection blocked by the Volkerak dam at the end of the 1960s, followed by a new sluice regime preventing salt water intrusion inland in 1970. These disturbances might have led to a second wave of exploding populations of opportunists. In the Haringvliet, Streblospio shrubsolii and Boccardiella ligerica were responsible for the temporary high densities; in the Hollandsch Diep, it was Heteromastus filiformis. In the Voordelta at the end of the 1960s, Spiophanes bombyx and Spio martinensis became temporarily abundant. After the onset of the new sluices regime, environmental conditions stabilized at a level of low variability. However, conditions deteriorated due to high nutrient and pollutant levels in combination with less water exchange and possibly poorer oxygen conditions (Fig. 2.). The new communities of the 1970s were, therefore, species poor and showed low diversity and low total macrofauna numbers (Fig. 3). These observations are in line with the patterns described by Pearson \& Rosenberg (1978) for macrobenthic succession in relation to organic enrichment and pollution, which play a role in our study throughout the 1960s and 1970s. However, during the 1960s the 2 major disturbances described above interfered or overruled the effect of the degradation of the quality of the system, and caused similar stress effects in macrobenthic communities. The macrobenthic responses in each of the basins looked generally the same, but differed somewhat in the details due to differences in severity of changes and differences in communities present at the time of disturbances. For instance, patterns are less clear in the Biesbosch and especially the Rivers. The reason for this is that disturbances (e.g. salinity changes, changes in currents, fluctuations in sediment loads) due to building activities are most severe and variable in the vicinity of the activities. Additionally, absolute changes in parameters like salinity and tidal amplitude between the situations before and after the closing of the system are smaller in the Biesbosch and the Rivers, as the values of those parameters already used to be low before closing. Observations are in line with the findings of Zajac \& Whitlatch (1982) who concluded amongst others that differences in habitat, timing, and the communities present led to variation in community succession after disturbances. 
With the gradual improvement of the water quality throughout the late 1970 s and 1980s, all 4 macrobenthic indicators went to a higher basic level than during the 1960s and early 1970s. The communities were found to be relatively species-rich and diverse at high densities, which is expected for relatively nutrient rich environments with intermediate water quality and low dynamics (Pearson \& Rosenberg 1978, Warwick 1986, Degraer et al. 2003). Over the last decade, a slight decrease in densities was observed co-occurring with a strong increase in species richness and diversity. This is in line with a further improvement of the underwater environment for which a decrease in densities is not uncommon (Dauer \& Alden 1995, Hewitt et al. 2005). In particular, the river water supplied to the area improved significantly in quality throughout the 1980s. This led to a gradual improvement of the water quality followed by an improvement of the quality of the sediment from east to west due to the combined effect of a shifted sedimentation front and the replenishment of potentially toxic substances from older sediment layers coming to the surface (Nienhuis 2008b). As the Voordelta remained a dynamic system, the richness and diversity did not increase and reach the same level as in the present low dynamic fresh water basins. Due to the large dynamics, total densities are particularly high in the Voordelta. Due to the redistribution of contaminated sediment from the east to the west, quality improvements and the effect on macrobenthic communities were observed first in the eastern part of the system. As a result, the increase in richness and diversity was observed earlier in the Hollandsch Diep and the Biesbosch, and richness and diversity are higher there at present than in the Haringvliet.

\section{Communities of the basins through time}

The communities of the Voordelta of the early 1960s were strongly influenced by large salinity fluctuations. During the 1960s the fresh water influence and, therefore, the salinity fluctuations decreased in a large part of the Voordelta, mainly the western part, which led to a divergence in species assemblages (Fig. 4a). The communities of the eastern Voordelta are most related to the communities of the period before closure, because of the strongly dynamic salt-brackish (mesoto polyhaline) environment. The communities in the western Voordelta are more poly- to mixoeuhaline related communities. From the early 1980s on, community changes were small, and between-communities variation was most related to spatial distribution of samples, i.e. differences between east and west related to the gradient of fresh water influence. By searching for potential reference communities for the Voordelta, we can distinguish 2 types for which the salt water community used to be present west of the area indicated as Voordelta in this study, during the period before the closure. The present Voordelta community does not differ much in distribution from the feeding guilds from the historic salt water community. Only suspension feeders are more abundant today, whereas abundances of surface deposit feeders and predators are reduced (Fig. 5). The present situation shows the pattern of a stable unpolluted environment (viz. high percentage of suspension feeders; Lavaleye et al. 2007). For the historic situation, suspension feeders were less abundant than surface deposit feeders on the seaward side. This might be an indication for the presence of more silty sediments (smaller grain size) and high organic matter and nitrogen contents (Roth \& Wilson 1998, Wieking \& Kröncke 2005). In the eastern part of the Voordelta it is likely that construction works already affected the communities by increasing suspended matter contents in the water column. Densities were therefore very low and suspension feeders almost lacking. Deposit feeders can profit from disturbed situations (Cheung et al. 2008) where dredging or comparable activities can support scavengers (Roth \& Wilson 1998, Dolbeth et al. 2009), which are visible in the proportion of predators. Although total densities are somewhat higher today in the Voordelta, species richness and diversity are comparable with the historic situation (Fig. 6), at least for the western part. The most frequently found species during the 1960s, i.e. Spiophanes bombyx, Magelona papillicornis and Nephtys cirrosa, still belong to the most abundant species at present. Species richness (a measure of average species density) is the same for the 2 periods, but at present more species can be found in the Voordelta as a whole. Some 'new-comers' that are abundant now are Urothoe poseidonis and Heteromastus filiformis, but the most abundant species at present is Ensis directus, an exotic species originating from North America and first observed in the Netherlands in the early 1980s (Wolff 2005).

Larger changes in community composition were expected east of the present Haringvliet dam. Fig. 3b shows that the construction works during the 1960s resulted in some convergence in the species assemblages. This is largely an effect of salinity fluctuations and shifts. The communities became poorer in species numbers and densities, but further community changes were minor. After complete closure during the 1970s, the communities of brackish dynamic environments were replaced by fresh water species of a stable envi- 
ronment, although in the most western and deepest parts, some brackish elements persisted until 1973. From the end of the 1970s onward, communities of eutrified and polluted fresh waters developed from east to west. Since the early 1990s, the water quality has significantly improved, and changes in species composition are only minor. Comparing the present community with the historic one shows that they are completely different systems which have no species in common. The historic brackish-dynamic community had close similarities with the historic salt-brackish community of the Voordelta. All observed species showed good persistence against large salinity fluctuations; Boccardiella ligerica and Polydora ligni were abundant, and Nereis diversicolor was found in almost all available samples. The assemblages at present are dominated by the genera Procladius, Pisidium and Corbicula, of which the Corbicula species are exotics originating from southeast Asia, first observed in the Netherlands in the late 1980s (Wolff 2005). The present species assemblages are relatively insensitive to nutrients and pollutants, as indicated by the abovementioned dominant species groups (Krieger 1984, Peeters et al. 2008a). Therefore, the Haringvliet can still not be considered clean, because pollutant-sensitive species have not colonized the basin. The distribution over the feeding guilds for the historic and present communities looks surprisingly the same with suspension feeders dominating and only some omnivores exchanged for predators (Fig. 5). The dominance of deposit feeders and a good representation of the other feeding guilds show that the environment is relatively stable, unpolluted and unstressed (Lavaleye et al. 2007). For the present situation the relative high proportion of predators in combination with suspension feeders might indicate the final stage of succession (Roth \& Wilson 1998). For the historic situation this does not mean that the environment was not dynamic but rather that it was a stable dynamic environment without unexpected disturbances. The lack of herbivores shows that shallow environments are scarce in the Haringvliet (Dolbeth et al. 2009). Species diversity, richness and evenness are much higher at present (Fig. 6) which is to be expected in stable fresh water conditions, compared to a highly dynamic historic situation with brackish water (Remane 1934, Dauvin 2007).

During the 1960s, the communities started to change in the Hollandsch Diep due to the construction works; the dynamics of salinity changed and tides were suppressed. The brackish-fresh water communities of a dynamic environment gradually changed into those of a stable environment. During the 1970s, the fresh water influences were becoming dominant within the communities, followed by some improvement of the water quality (from eutrified and polluted to cleaner and less nutrient-rich). From the late 1970s and early 1980 s to the early 1990s, the communities of stable, nutrient-rich, polluted, fresh water changed into communities of better quality, stable, fresh waters. Further community developments were only minor. The historic communities of the Hollandsch Diep were quite similar to those of the Haringvliet at that time, as both basins have comparable salinity conditions, particularly at the bottom, due to direct salt water inflow. Nereis diversicolor is particularly abundant and Boccardiella ligerica reaches high densities locally in the historic situation of the Hollandsch Diep. The presence of typical oligohaline species like Gammarus zaddachi indicates a strong fresh-salt stratification in the historic situation. At present, the community of the Hollandsch Diep is completely dominated by exotic species, including Potamopyrgus antipodarum, Corbicula sp., Hypania invalida, G. tigrinus, Limnomysis benedeni, Jaera istri and Dreissena polymorpha. Indigenous species like Valvata piscinalis and Cladotanytarsus sp. complete the species rich and abundant community (Fig. 6). Several of these species can cope with mesohaline conditions, but all of the species can live in fresh water. Whereas the historic community consisted solely of suspension feeders, surface deposit feeders and omnivores, which might indicate high amounts of quality food present at that time (Wieking \& Kröncke 2005), currently also deposit feeders, herbivores and predators, are relative abundant (Fig. 5). The present situation reflects a stable and good quality environment, although completely dominated by non-indigenous species.

Data from before 1965 are lacking for the Biesbosch, yet the communities of the mid 1960s are still representative for a tidal fresh environment. The communities of the early 1970s are however completely different from those of the mid 1960s (Fig. 4d). During the late 1960s the communities must have changed from tidal fresh water with small salt influences to a poor community with a few fresh water species, which are representative of the nutrient rich, polluted, stagnant, fresh water environment. In the 1990s, the water quality had already improved significantly, and communities showed little further change. The historic tidal fresh water community was dominated by Pisidium species and the brackish water species Gammarus zaddachi. As the densities and species richness were low for the historic community, it seems that pollution must have already played a role by the mid 1960s. This is supported by the dominance of Pisidium species that are relatively indifferent to pollutants (Peeters et al. 2008b). Pollutant and nutrient influences at the fresh 
water side of estuaries have been found more often, for instance as shown for the Westerschelde and the Eems (Ysebaert et al. 1998). As indicated by the species composition, there must have been some occasional salt intrusion into the Biesbosch waters during the 1960s. Tidal fresh water is expected to be relatively species rich. However, occasional increased salinity might explain the low species numbers observed. Moreover, incidental brackish water supply can lead to a substrate that contains salty elements for a long time.

The present communities of the Biesbosch still consist of relatively indifferent species (i.e. species with a broad ecological niche), but are otherwise quite diverse with high densities and species numbers (Fig. 6). Frequently observed species are Einfeldia carbonaria, Valvata piscinalis and Corbicula sp., while Tubificidae, Vejdovskyella intermedia and Cladotanytarsus sp. can reach high densities in the Biesbosch. In the historic community the dominant feeding guilds, in order of importance, were the predators, the herbivores, and the deposit feeders. The dominance of predators and deposit feeders also indicates that the communities of the mid 1960s were already deteriorated due to pollution. The large quantity of herbivores was probably related to the specific characteristics of the system (Dolbeth et al. 2009), with a large part consisting of relatively shallow gullies where macrophytes and marshy vegetation flourished (Nienhuis 2008a). At present the deposit feeders form almost half of the macrofauna communities of the Biesbosch, and compared to the other basins, the suspension feeders are relatively scarce, which is typical for fine sandy to muddy areas with high organic contents (Wieking \& Kröncke 2005, Dolbeth et al. 2009).

Despite the heterogeneity of the basin Rivers (indicated by the significant differences between the regions), there are also clear community developments over time. As for the Biesbosch, the communities of the Rivers were already influenced by pollution by the mid 1960s. Therefore, a relatively species-poor community with Pisidium supinum, Sphaerium corneum and Chironomus reductus as the most abundant species was found. In this historic community, the suspension feeders were dominant. At present the communities of the Rivers are species rich and reach high densities (Fig. 6). The proportion of deposit feeders has increased relative to the number of suspension feeders, and predators are more abundant now. This indicates that the importance of mud and organic matter in the present system is greater than in the historic situation. At present the numbers of macrozoobenthos in the Rivers are more or less equally distributed over the suspension feeders, the deposit feeders, and the sur- face deposit feeders, and the other feeding guilds are of minor importance (Fig. 5). All species found in the Rivers today are specific to fresh water, but several of the species can also withstand higher salinities, which might indicate that pure fresh water conditions are not always present in the Dutch Rivers and that the conductivity of the river water is elevated due to the continued addition of ions via water run-off from agriculture, urbanized areas, industries, and mining activities. Abundant genera at present are Corbicula, Cladotanytarsus, Corophium and Limnodrilus.

As for the community descriptors, the largest changes in community assemblages occurred during the 1970s and 1980s (e.g. Fig. 4), indicating that after that communities adapted to the new conditions after the construction of the dam, and that the further minor changes are the result of continued processes like water quality improvements or the arrival of exotic species.

\section{An open estuary is preferable from a macrobenthic point of view}

In general, historic communities from the early 1960s were quite variable in terms of macrobenthic indicators and distribution over the feeding guilds. This variety is partly related to the initial influences of ongoing construction works on the environment and the macrobenthic communities and the subsequent decrease in water and sediment quality, particularly in the east. The additional negative effects from low water and sediment quality (i.e. pollution) led to poorer communities and a loss of certain species in the later 1960s rather than a simple transition to a complete new species assemblage, as also indicated by Fig. 4. From the 1970s on, a transition took place, whereby the deteriorated communities were replaced by species assemblages belonging to the newly created systems, i.e. low dynamic fresh water systems east of the dam. Using the historic communities from the 1960s as references in Fig. 4 may underestimate to some extent the richness and diversity of an undisturbed estuary, as these communities were influenced by the presence of pollution and nutrients. However, this is the closest available representation of an undisturbed open system. The historic communities described here likely give a good indication of the community structures that can be expected after restoration of the estuary. However, compared to the historic situation, the species richness will likely be higher after restoration as the nutrient and pollutant status (Hall et al. 1996) is much better at present.

The historic aggregates (as opposed to the aggregates of the current situation) in the nMDS analysis 
(Fig. 7) indicate that there is not only a gradient from west to east in several of the abiotic parameters (e.g. salinity, salinity variance, tidal and current dynamics), but that this also leads to a clear gradient in macrobenthic communities. The current communities were shown to be quite similar in composition according to the proportional distribution over the feeding guilds, with suspension feeders most abundant (Fig. 5), which in general can be described as the distribution of a healthy system in terms of water quality and disturbance (e.g. Dauer \& Alden 1995, Ysebaert et al. 2003). The various locations are, therefore, quite similar within the entire system today, only separated in a salt (North Sea bound) and a fresh water community. For the fresh water community, only some variation is found in the samples from the Rivers where a somewhat larger spectrum in dynamics, currents and influences of nutrients and pollutants is present. The larger role of pollutants in one river arm than the other may also have caused the larger differentiation for the historic River communities compared to the other basins. Pollutant inputs differ for instance between Rhine and Meuse fed stretches (Admiraal et al. 1993), and influences might be varied between stretches with differences in dynamics, salinities, $\mathrm{pH}$, or organic matter contents due to effects of water turnover, chemical binding, speciation and flocculation (Luoma 1983).

Taking the macrobenthic diversity of the entire system into account, it must be concluded that the former estuarine situation was more diverse (Fig. 8, Table 3), and thereby maybe more valuable, than the closed system of today. The highly dynamic and changing conditions in the past led to a variety of niches, distributed in a stratified way: horizontally, vertically, and temporally. Specific species could be locally or temporally abundant. At present, the conditions are very stable and variation is small. This is indicated by the fact that 10 randomly taken samples always resulted in more or less the same community describing a basin or even the whole fresh water part (Fig. 8, Table 3). The same set of (dominant) species can be observed in the entire fresh water area. Typical species for such conditions are those with a cosmopolitan distribution to which many exotic species today belong. Already at the basin level, variation appeared to be larger during the historic situation, as indicated by the fact that 10 random samples generally do not result in the same compiled community; however the basins Rivers and Hollandsch Diep are exceptions. The total diversity for the entire system appears to be at least twice as high as indicated by the results on average community similarity (Table 3). However, a much larger total number of species in the entire system is found for the present situation compared to the historic situation (Fig. 9). On the one hand, this is probably the result of the relatively deteriorated state of the system, due to elevated pollutant and nutrient levels at that time. On the other hand, larger fluctuations in salinity and extended regions with brackish conditions will naturally harbor lower numbers of species than low-dynamic fresh water environments. For the region where least has changed in the environmental conditions - the western part of the Voordelta (VD1) - the Margalef richness is similar for the present and historic situation (Fig. 6). Densities used to be lower, so this means that a lower total number of species was recorded for the historic communities, whereas one would expect similar numbers of species when the environmental state is about the same. Whether an open estuarine system will harbor higher total numbers of species remains a question, but the total diversity is expected to be much higher.

If productivity, in terms of macrobenthic densities for the entire region, is valued the most, the current situation should be maintained. This might be a realistic selection criterion when important food sources or prey species for highly appreciated species of for instance, fish, birds, or mammals, including humans (Ysebaert et al. 1998), form an important part of the present communities. However, in terms of biomass it is not certain whether the current situation is preferable, as some larger species (especially molluscs) can be very abundant in the dynamic brackish and salt-brackish waters (Ysebaert et al. 1998, 2003) that are lacking in the present situation.

\section{Future developments}

A frequently asked question is whether a return to the reference situation is possible. If abiotic conditions were restored, it is still unlikely that the same communities as before the closing of the system would return. At present a completely different species assemblage exists in the area, partly due to new invading species, whereas several species which used to be present are absent from the entire region and beyond. Colonization of preferred biotopes for these last species can therefore be hampered by the presence of physical barriers and a lack of sources for recolonization. Moreover, colonizing species have to compete with other species that are already present, whereby it is questionable whether all current species will disappear with changing conditions. Nevertheless, some general parameters as community structures (e.g. distribution over feeding guilds and diversity) and productivity (e.g. densities) might be predictable to a certain extent. 
The regulated salt intrusion into the system is planned to reach only $11.5 \mathrm{~km}$ inland. Although this appears to be a restoration of the salt to fresh water gradient, the maintenance of only a restricted salt intrusion will lead to a situation where such a gradient is only present temporarily. At times of low river water runoffs, the sluices of the Haringvliet dam will be closed during high tide and opened during low tide to prevent salt intrusion inland. With such a sluice regime, water can only flow out. This will lead to a situation where the western part of the Haringvliet will be flushed with fresh water. Calculations showed that such a situation will occur 2 to 3 times a year on average, lasting several months in total (Wijnhoven et al. 2008). These plans for a temporary salt-fresh gradient which constantly changes into a fresh water situation might be sufficient to restore the connectivity of the inland waters with the sea for catadromous and anadromous fish. However, for the macrozoobenthic communities such a situation might lead to a permanently disturbed area. Regime changes are either too frequent or not frequent enough to reach and maintain stable communities of dynamic environments. Communities will get stuck in the opportunistic species phase which has low diversity or will go to a species-poor community in which a few opportunistic species outnumber the others. One might compare such a situation to the state of fluctuations observed during and directly after the closing of the dam except that it would re-occur year after year.

\section{CONCLUSIONS}

The present study shows that large long-term macrozoobenthic datasets are very valuable to evaluate developments in (artificially) changing systems and to foresee future changes in the communities after restoration measures, despite possible irregularities in sampling intensities, methodologies, and the presence of multiple co-occurring factors influencing communities. Because communities change with large fluctuations following restoration measures, it is of particular importance for evaluation applications to monitor with sufficient frequency (at least every year), during and after the measures. The findings show that about $5 \mathrm{yr}$ after the closing of the estuary, communities were still changing as a response to changed conditions. Stabilization of communities after closing takes at least a decade. 'Stable' communities can be observed in the upstream region first, as environmental changes are smaller and more gradual there than near the building site (i.e. the direct impact zone). Although as a refer- ence, historic macrobenthic information from before construction works is preferred, monitoring data of systems already in change can also be used to construct a reference for future restoration plans. The reliability of a system's reference is however determined by the temporal and spatial data distribution and density. In this study the historic communities could not be considered the perfect reference for an open, undisturbed system. The nMDS, however, appeared to be a useful and powerful tool to evaluate community structure and diversity and yielded good indications of what a reference for the region should look like.

Macrozoobenthic communities, as in the RhineMeuse estuary, indicate the state of the environment. Major disturbances will lead to an increase of densities and a decrease in species richness and diversity. When the new conditions balance, the densities drop. Deteriorated conditions are characterized by low species richness and low diversity with high densities under nutrient-rich conditions without hypoxia. Dynamic environments have lower species richness and diversity than stable environments (Attrill 2002), can be resistant against deterioration (Hummel et al. 2011), and densities can be higher. Species richness is generally higher in marine and fresh waters than in brackish water (Remane 1934). The effects of nutrients and pollutants are, however, generally more severe on the fresh water side of estuaries. Species richness in the oligohaline parts of several West European estuaries is therefore low (Hall et al. 1996). With improved water quality (e.g. lowering of nutrient and pollutant concentrations), a shift from deposit feeder dominated communities to suspension feeder dominated communities can be expected, co-occurring with increasing species richness and diversity and generally decreasing densities, but with increasing biomass. A large percentage of suspension feeders generally indicates an anthropogenically undisturbed, good quality environment. In such an environment other feeding guilds are also present. In more silty environments (e.g. in many standing waters), the proportion of suspension feeders is naturally reduced, and surface deposit feeders are more abundant. Such environments are more susceptible to higher nutrient inputs. At larger disturbances, deposit feeders flourish, generally followed by a number of predators. In good quality shallow environments herbivores can be particularly abundant.

Currently, the number of non-indigenous species and their densities are high in the former Rhine-Meuse estuary. Although brackish waters, due to their natural low species richness, are expected to be more susceptible towards invasions of exotic species, exotic species dominate the fresh waters in the Rhine-Meuse estuary. 
This might be the result of fresh waters being more susceptible to pollutants and nutrients, resulting in impoverished communities and plenty of niches available for invaders.

Irrespective of the relatively low species richness and diversity observed on local spots, the overall diversity of the entire Rhine-Meuse estuary appeared to be much higher in the case of an unregulated estuary than in the present state with a marine Voordelta separated from a series of fresh water basins. It is expected that species richness can potentially also be higher at good quality (i.e. decreased nutrient inputs and low pollutant concentrations) conditions in an open estuary. Therefore from a macrozoobenthic diversity point of view, a restoration of the salt to fresh water gradient and the dynamics in the former Rhine-Meuse estuary region is recommended. Care has to be taken as to the frequency of the salt intrusions since an irregular intrusion of salt water, other than tidal, as planned for the western part of the Haringvliet, may hamper a healthy successional community development leaving it in a permanently disturbed phase.

Acknowledgements. The authors thank the 'Waterdienst' of Rijkswaterstaat (RWS), who supported this research by funding a desk study on the historic developments of the macrozoobenthic communities of the Rhine-Meuse estuary. We are particularly grateful to B. Reeze who enabled the underlying project and to E. Peeters (Wageningen University) and M. de la Haye (Grontmij/Aquasense) who compiled and kindly made available part of the data. This is publication no. 5048 of the Netherlands Institute of Ecology (NIOO-KNAW) and Monitor Taskforce Publication Series 2011-06.

\section{LITERATURE CITED}

> Admiraal W, Van der Velde G, Smit H, Cazemier WG (1993) The rivers Rhine and Meuse in The Netherlands: present state and signs of ecological recovery. Hydrobiologia 265: 97-128

Attrill MJ (2002) A testable linear model for diversity trends in estuaries. J Anim Ecol 71:262-269

Backx JJGM, Van den Berg G, Geilen N, De Hoog A and others (2002) Heavily modified waters in Europe. Case study on the Haringvliet estuary. Report RIZA, Dordrecht

Bate GC, Whitfield AK, Adams JB, Huizinga P, Wooldridge $\mathrm{TH}$ (2002) The importance of the river-estuary interface (REI) zone in estuaries. Water SA 28:271-279

> Beck MW, Heck KL Jr, Able KW, Childers DL and others (2001) The identification, conservation, and management of estuarine and marine nurseries for fish and invertebrates. Bioscience 51:633-641

Boudewijn TJ, Van Dam EM, De Ridder RP (2004) Sliedrechtse Biesbosch op de schop! Levende Nat 105:87-92

> Cheung SG, Lam NWY, Wu RSS, Shin PKS (2008) Spatio-temporal changes of marine macrobenthic community in subtropical waters upon recovery from eutrophication. II. Life-history traits and feeding guilds of polychaete community. Mar Pollut Bull 56:297-307
Clarke KR, Gorley RN (2001) Primer v5: User Manual/ Tutorial. Primer-E, Plymouth

Costanza R, D'Arge R, De Groot R, Farber S and others (1997) The value of the world's ecosystem services and natural capital. Nature 387:253-260

Dauer DM, Alden RW III (1995) Long-term trends in the macrobenthos and water quality of the lower Chesapeake Bay (1985-1991). Mar Pollut Bull 30:840-850

> Dauvin JC (2007) Paradox of estuarine quality: Benthic indicators and indices, consensus or debate for the future. Mar Pollut Bull 55:271-281

> Degraer S, Volckaert A, Vincx M (2003) Macrobenthic zonation patterns along a morphodynamical continuum of macrotidal, low tide bar/rip and ultra-dissipative sandy beaches. Estuar Coast Shelf Sci 56:459-468

Dolbeth M, Teixeira H, Marques JC, Pardal MÂ (2009) Feeding guild composition of a macrobenthic subtidal community along a depth gradient. Sci Mar 73:225-237

Hall JA, Frid CLJ, Proudfoot RK (1996) Effects of metal contamination on macrobenthos of two North Sea estuaries. ICES J Mar Sci 53:1014-1023

Hastie BF, Smith SDA (2006) Benthic macrofaunal communities in intermittent estuaries during a drought: comparisons with permanently open estuaries. J Exp Mar Biol Ecol 330:356-367

Hewitt JE, Anderson MJ, Thrush SF (2005) Assessing and monitoring ecological community health in marine systems. Ecol Appl 15:942-953

Hummel H, Sokołowski A, Hummel C, Wijnhoven S (2011) Tolerance to natural environmental change and the effect of added chemical stress. In: Amiard-Triquet C, Rainbow PS, Roméo M (eds) Tolerance to environmental contaminants. CRC Press, Boca Raton, FL, p 109-124

Krieger KA (1984) Benthic macroinvertebrates as indicators of environmental degradation in the southern nearshore zone of the central basin of lake Erie. J Gt Lakes Res 10: 197-209

Lavaleye M, Craeymeersch JA, Duineveld GCA (2007) Functional diversity. In: Rees HL, Eggleton JD, Rachor E, Vanden Berghe E (eds) Structure and dynamics of the North Sea benthos. ICES Cooperative Research Report 288:109-115

Luoma SN (1983) Bioavailability of trace metals to aquatic organisms - a review. Sci Total Environ 28:1-22

Nienhuis PH (2008a) Changes in biodiversity: Lower organisms, vegetation and flora. In: Nienhuis PH (ed) Environmental history of the Rhine-Meuse delta. Springer Science + Business Media, Dordrecht, p 481-507

Nienhuis PH (2008b) The making of the Delta. In: Nienhuis $\mathrm{PH}$ (ed) Environmental history of the Rhine-Meuse delta. Springer Science + Business Media, Dordrecht, p 539-561

Nienhuis PH, Huis in't Veld JC (1984) Grevelingen: from an estuary to a saline lake. Water Sci Technol 16:27-50

Nienhuis PH, Smaal AC (1994) The Oosterschelde estuary, a case-study of a changing ecosystem: an introduction. Hydrobiologia 282-283:1-14

Pearson TH, Rosenberg R (1978) Macrobenthic succession in relation to organic enrichment and pollution of the marine environment. Oceanogr Mar Biol Annu Rev 16:229-311

Peeters ETHM, De Lange HJ, De la Haye MAA (2008a) KRWMaatlat macrofauna voor zoet getijdenwater (uitlopers rivier) op zand/klei (R8). Report Wageningen UR, Wageningen

Peeters ETHM, De Lange HJ, De la Haye MAA, Rutjes HA, Janmaat LM (2008b) Achtergrondrapport KRW-maatlat 
macrofauna R8. Bewerking en analyse data. Report Wageningen, UR Wageningen

Petersen JK, Hansen JW, Laursen MB, Clausen P, Carstensen J, Conley DJ (2008) Regime shift in a coastal marine ecosystem. Ecol Appl 18:497-510

Quintino V, Elliott M, Rodrigues AM (2006) The derivation, performance and role of univariate and multivariate indicators of benthic change: Case studies at differing spatial scales. J Exp Mar Biol Ecol 330:368-382

Remane A (1934) Die Brackwasser Fauna. Verh Dtsch Zool Ges 1933:34-74

Roth S, Wilson JG (1998) Functional analysis by trophic guilds of macrobenthic community structure in Dublin Bay, Ireland. J Exp Mar Biol Ecol 222:195-217

Sanders HL (1968) Marine benthic diversity: a comparative study. Am Nat 102:243-282

Shaffer JA, Crain P, Winter B, McHenry ML, Lear C, Randle TJ (2008) Nearshore restoration of the Elwha River through removal of the Elwha and Glines Canyon dams: an overview. Northwest Sci 82:48-58

Teske PR, Wooldridge T (2001) A comparison of the macrobenthic faunas of permanently open and temporarily open/closed South African estuaries. Hydrobiologia 464: 227-243

Vaas KF (1961) De taak en het arbeidsveld van de Afdeling Delta-Onderzoek van het Hydrobiologisch Instituut te Yerseke. Vakbl Biol 41:6-13

- Warwick RM (1986) A new method for detecting pollution effects on marine macrobenthic communities. Mar Biol 92:557-562

West EJ, West RJ (2007) Growth and survival of the invasive alga, Caulerpa taxifolia, in different salinities and temper-

Editorial responsibility: Lisandro Benedetti-Cecchi, Pisa, Italy atures: implications for coastal lake management. Hydrobiologia 577:87-94

Wieking G, Kröncke I (2005) Is benthic structure affected by food quality? The Dogger Bank example. Mar Biol 146: $387-400$

Wijnhoven S, Sistermans W, Hummel H (2008) Historic developments in macrozoobenthos of the Rhine-Meuse estuary: From a tidal inlet to a freshwater lake. Estuar Coast Shelf Sci 76:95-110

Wijnhoven S, Escaravage V, Daemen EAMJ, Hummel H (2010) The decline and restoration of a coastal lagoon (Lake Veere) in the Dutch Delta. Estuaries Coasts 33: 1261-1278

Wolanski E, Chicharo L, Alexandra Chicharo M, Morais P (2006) An ecohydrology model of the Guadiana Estuary (South Portugal). Estuar Coast Shelf Sci 70:132-143

Wolff WJ (1973) The estuary as a habitat. An analysis of data on the soft-bottom macrofauna of the estuarine area of the rivers Rhine, Meuse, and Scheldt. Zool Verh 126:1-242

Wolff WJ (2005) Non-indigenous marine and estuarine species in the Netherlands. Zool Meded 79:1-116

> Ysebaert T, Meire P, Coosen J, Essink K (1998) Zonation of intertidal macrobenthos in the estuaries of Schelde and Ems. Aquat Ecol 32:53-71

Ysebaert T, Herman PMJ, Meire P, Craeymeersch J, Verbeek H, Heip CHR (2003) Large-scale spatial patterns in estuaries: estuarine macrobenthic communities in the Schelde estuary, NW Europe. Estuar Coast Shelf Sci 57: 335-355

> Zajac RN, Whitlatch RB (1982) Responses of estuarine infauna to disturbance. II. Spatial and temporal variation of succession. Mar Ecol Prog Ser 10:15-27

Submitted: September 11, 2010; Accepted: May 12, 2011

Proofs received from author(s): August 23, 2011 